\title{
Auxiliary role of mesenchymal stem cells as regenerative medicine soldiers to attenuate inflammatory processes of severe acute respiratory infections caused by COVID-19
}

\author{
Peyvand Parhizkar Roudsari • Sepideh Alavi-Moghadam • Moloud Payab (1) \\ Forough Azam Sayahpour · Hamid Reza Aghayan (D) Parisa Goodarzi • \\ Fereshteh Mohamadi-jahani • Bagher Larijani $(\mathbb{D} \cdot$ Babak Arjmand $\mathbb{D}$
}

Received: 17 April 2020/Accepted: 13 June 2020/Published online: 25 June 2020

(C) Springer Nature B.V. 2020

\begin{abstract}
Acute respiratory infections as one of the most common problems of healthcare systems also can be considered as an important reason for worldwide morbidity and mortality from infectious diseases. Coronaviruses are a group of well-known respiratory viruses that can cause acute respiratory infections. At the current state, the 2019 novel coronavirus is cited as the most worldwide problematic agent for the respiratory system. According to investigations, people
\end{abstract}

P. Parhizkar Roudsari · B. Arjmand ( $₫)$

Metabolomics and Genomics Research Center, Endocrinology and Metabolism Molecular-Cellular Sciences Institute, Tehran University of Medical Sciences, Tehran, Iran

e-mail: barjmand@sina.tums.ac.ir

P. Parhizkar Roudsari

e-mail: Peyvand.parhizkar@yahoo.com

S. Alavi-Moghadam · H. R. Aghayan · B. Arjmand

Cell Therapy and Regenerative Medicine Research

Center, Endocrinology and Metabolism Molecular-

Cellular Sciences Institute, Tehran University of Medical

Sciences, Tehran, Iran

e-mail: sepidalavi@gmail.com

H. R. Aghayan

e-mail: hr.aghayan@gmail.com

M. Payab

Obesity and Eating Habits Research Center,

Endocrinology and Metabolism Molecular-Cellular

Sciences Institute, Tehran University of Medical Sciences,

Tehran, Iran

e-mail: Moloudpayab@gmail.com with old age and underlying diseases are at higher risk of 2019 novel coronavirus infection. Indeed, they may show a severe form of the disease (with severe acute respiratory infections). Based on the promising role of cell therapy and regenerative medicine approaches in the treatment of several life-threatening diseases, it seems that applying cell-based approaches can also be a hopeful strategy for improving subjects with severe acute respiratory infections caused by the 2019 novel

\author{
F. A. Sayahpour \\ Department of Stem Cells and Developmental Biology, \\ Cell Science Research Center, Royan Institute for Stem \\ Cell Biology and Technology, ACECR, Tehran, Iran \\ e-mail: fa_rosacea@yahoo.com \\ P. Goodarzi · F. Mohamadi-jahani \\ Brain and Spinal Cord Injury Research Center, \\ Neuroscience Institute, Tehran University of Medical \\ Sciences, Tehran, Iran \\ e-mail:pr_goodarzi@yahoo.com \\ F. Mohamadi-jahani \\ e-mail: f.mohamadijahani@gmail.com \\ B. Larijani \\ Endocrinology and Metabolism Research Center, \\ Endocrinology and Metabolism Clinical Sciences \\ Institute, Tehran University of Medical Sciences, Tehran, \\ Iran \\ e-mail: emrc@tums.ac.ir
}


coronavirus. Herein, due to the amazing effects of mesenchymal stem cells in the treatment of various diseases, this review focuses on the auxiliary role of mesenchymal stem cells to reduce inflammatory processes of acute respiratory infections caused by the 2019 novel coronavirus.

Keywords ARDS · Cell therapy · Coronavirus · COVID-19 - Mesenchymal stem cells · Pneumonia · Regenerative medicine

$\begin{array}{ll}\text { Abbreviations } \\ \text { ARIs } & \text { Acute respiratory infections } \\ \text { RV } & \text { Rhinovirus } \\ \text { CoV } & \text { Coronavirus } \\ \text { RSV } & \text { Respiratory syncytial virus } \\ \text { SARS } & \text { Severe acute respiratory syndrome } \\ \text { MERS } & \text { Middle east respiratory syndrome } \\ \text { COVID- } & \text { Coronavirus disease 2019 } \\ \text { 19 } & \\ \text { WHO } & \text { World Health Organization } \\ \text { ARDS } & \text { Acute respiratory distress syndrome } \\ \text { HFNOT } & \text { High-flow nasal oxygen therapy } \\ \text { PEEP } & \text { Positive end-expiratory pressure } \\ \text { RMs } & \text { Recruitment maneuvers } \\ \text { ECMO } & \text { Extracorporeal membrane oxygenation } \\ \text { CTRM } & \text { Cell therapy and regenerative medicine } \\ \text { MSC } & \text { Mesenchymal stem cell } \\ \text { BM } & \text { Bone marrow } \\ \text { AT } & \text { Adipose tissue } \\ \text { PL } & \text { Placenta } \\ \text { UC } & \text { Umbilical cord } \\ \text { ICU } & \text { Intensive care unit } \\ \text { AEs } & \text { Acute exacerbations } \\ \text { COPD } & \text { Chronic obstructive pulmonary disease } \\ \text { CF } & \text { Cystic fibrosis } \\ \text { HMPV } & \text { Human metapneumovirus } \\ \text { HBoV } & \text { Human bocavirus } \\ \text { AIDS } & \text { Acquired immunodeficiency syndrome } \\ \text { CAP } & \text { Community acquired pneumonia } \\ \text { HpeV } & \text { Human parechovirus } \\ \text { EBV } & \text { Epstein-Barr virus } \\ \text { HSV } & \text { Herpes simplex virus } \\ \text { CMV } & \text { Cytomegalovirus } \\ \text { HIV } & \text { Human immunodeficiency viruses } \\ \text { HCoVs } & \text { Human coronaviruses } \\ \text { 2019- } & \text { 2019 Novel coronaviruses } \\ \text { nCoV } & \end{array}$

CBC Complete blood count

CRP C-reactive protein

ELISA Enzyme-linked immunosorbent assay

RT-PCR Reverse transcription-polymerase chain reaction

$\begin{array}{ll}\text { ALI } & \text { Acute lung injury } \\ \text { NIV } & \text { Noninvasive ventilation } \\ \text { HEV } & \text { Human enteroviruses } \\ \text { ACE2 } & \text { Angiotensin-converting enzyme 2 } \\ \text { CFR } & \text { Case fatality rate } \\ \text { PTSS } & \text { Posttraumatic stress symptoms } \\ \text { MODS } & \text { Multiple organ dysfunction syndromes } \\ \text { CDC } & \text { Centers for disease control } \\ \text { MOF } & \text { Multiple organ failure } \\ \text { ORF } & \text { Open reading frame } \\ \text { nsps } & \text { Non-structural proteins } \\ \text { mRNA } & \text { Messenger RNA } \\ \text { ER } & \text { Endoplasmic rreticulum } \\ \text { IL } & \text { Interleukin } \\ \text { TNF- } \alpha & \text { Tumor necrosis factor- } \alpha \\ \text { LDH } & \text { Lactate dehydrogenase } \\ \text { FGF } & \text { Fibroblast growth factor } \\ \text { GCSF } & \text { Granulocyte colony-stimulating factor } \\ \text { GMCSF } & \text { Granulocyte-macrophage colony- } \\ & \text { stimulating factor } \\ \text { IFN } & \text { Interferon } \\ \text { IP10 } & \text { Interferon-induced protein10 } \\ \text { MCP } & \text { Monocyte chemoattractant protein } \\ \text { PDGF } & \text { Platelet-derived growth factor } \\ \text { VEGF } & \text { Vascular endothelial growth factor } \\ \text { CCR } & \text { Chemokine receptor } \\ \text { ESR } & \text { Erythrocyte sedimentation rate } \\ \text { SAA } & \text { Serum amyloid A } \\ \text { AST } & \text { Aspartate aminotransferase } \\ \text { FIB } & \text { Fibrinogen } \\ \text { Th } & \text { T helper } \\ \text { TGF- } \beta & \text { Transforming growth factor beta } \\ \text { PVD } & \text { Patient-ventilator dyssynchrony } \\ \text { CT } & \text { Computed tomography } \\ \text { TE } & \text { Tissue engineering } \\ \text { HEV } & \text { Human enteroviruses } \\ & \end{array}$

\section{Introduction}

Acute respiratory infections (ARIs) (due to high prevalence) are one of the most common problems 
and concerns of the healthcare systems. Indeed, ARIs can be considered as the major cause of morbidity and mortality from infectious diseases worldwide (Bulla and Hitze 1978; Graham 1990; Caballero et al. 2018). The most important agent of ARIs which can cause a wide range of infections in the upper and lower respiratory tract are viruses (Leung et al. 2020; Bhuyan et al. 2017; Botti et al. 2018). Here, more well-known respiratory viruses are influenza, parainfluenza, rhinovirus (RV), coronavirus (CoV), adenovirus, and respiratory syncytial virus (RSV) (Nichols et al. 2008; Modena et al. 2011; Pham et al. 2020). CoVs are a large family of viruses ranging from the common cold virus to the causes of more serious diseases such as severe acute respiratory syndrome (SARS), middle east respiratory syndrome (MERS), and CoV disease 2019 (COVID-19) (Jiang et al. 2020; Paules et al. 2020). Currently (in 2019-2020), COVID-19 is cited as one of the most problematic and novel zoonotic diseases of the respiratory system around the world. COVID-19 was first reported in Wuhan, China, in December 2019. Subsequently, on 11 March 2020, the world health organization (WHO) declared it as a pandemic disease (Mackenzie and Smith 2020; Organization and Organization 2020). According to the WHO announcement, common symptoms of COVID-19 which can occur within 2-14 days are including fever and chills, fatigue, dry cough, shortness of breath, sputum production, myalgia or arthralgia, headache, and sore throat. Of course, few people also show symptoms such as diarrhea,

Table 1 Common symptoms of COVID-19 (Organization and Organization 2020)

\begin{tabular}{lc}
\hline Symptoms & Percentage \\
\hline Fever & 87.9 \\
Dry cough & 67.7 \\
Fatigue & 38.1 \\
Sputum production & 33.4 \\
Shortness of breath & 18.6 \\
Sore throat & 13.9 \\
Headache & 13.6 \\
Myalgia or arthralgia & 14.8 \\
Chills & 11.4 \\
Nausea or vomiting & 5.0 \\
Nasal congestion & 4.8 \\
Diarrhea & 3.7 \\
\hline
\end{tabular}

vomiting, and runny nose (Cascella et al. 2020; Organization and Organization 2020). Herein, Table 1 shows the percentages of these symptoms in COVID19 cases. In addition, the majority of subjects infected with COVID-19 are reported to have mild to moderate illness and do not require serious treatment. However, the elderly people and those with cancer, diabetes, and cardiovascular and chronic respiratory disease along with subjects who have a poor immune system (for any reason e.g. organ transplantation) are at high risk of severe disease (Cascella et al. 2020; Heymann and Shindo 2020; Team 2020). In severe cases of COVID19 , intensive respiratory syndromes such as severe pneumonia and acute respiratory distress syndrome (ARDS) have been observed (Control 2020; Organization 2020). Pneumonia is an infection in which the air sacs in one or both lungs are inflamed. In critical cases, pneumonia is correlated with a progressed risk of ARDS (Turkington and Ashby 2007; Quinton et al. 2018). ARDS is a rapidly progressive disease which results in diffuse lung inflammation and following that increase vascular permeability pulmonary, interstitial space edema along with dysfunction of surfactant, immune system, and blood clotting system (Matuschak and Lechner 2010; Matthay et al. 2019). There are some treatment options for individuals who have a respiratory failure from ARDS secondary to COVID-19, such as high-flow nasal oxygen (HFNOT), tidal volume, plateau airway pressure, positive end-expiratory pressure (PEEP), neuromuscular blockade, prone positioning, recruitment maneuvers (RMs), fluid management, Inhaled NO, renal replacement therapy, extracorporeal membrane oxygenation (ECMO), and antibiotics (Matthay et al. 2020; Organization 2020). Generally, proposed treatments are often not a definite specific cure for COVID19 and they are directed to relieve symptoms (Jiang et al. 2020; Matthay et al. 2020). Therein, given this fact that cell therapy and regenerative medicine (CTRM) methods offer the chance of revolutionary approaches to delivering medicine (Arjmand et al. 2014; Goodarzi et al. 2019a, b), it seems that utilizing CTRM methods can also be a promising strategy for improving COVID-19 subjects with severe ARIs. On the other hand, many investigating efforts have shown that mesenchymal stem cell (MSC)-based therapies can be an innovative choice to treat ARI cases (Broekman et al. 2018; Harrell et al. 2019a, b, c; Chen et al. 2020a). In fact, MSCs which can be readily 
obtained from various tissues (e.g. bone marrow $(\mathrm{BM})$, adipose tissue (AT), placenta (PL), umbilical cord (UC), etc.) and have high-efficiency expansion potential can be effective through their limitless selfrenewal and multi-potential differentiation ability along with their paracrine mediators' association (Aghayan et al. 2014; Heo et al. 2016; Goodarzi et al. 2018a, b; Leng et al. 2020). Hereupon, this review focuses on the auxiliary role of MSCs to reduce inflammatory processes of severe ARIs in COVID-19 Cases.

\section{Overview of acute respiratory infections}

ARI is an acute infection of any part of the respiratory tract (included structures such as paranasal sinuses, middle ear, and pleural cavity) which can lead to inflammation from nose to alveoli (Pore et al. 2010). ARI is presented with cough accompanied by short and rapid breathing and it can even lead to death especially when it is associated with the other comorbidities (Dagne et al. 2020). Malnutrition, low birth weight, immunization, overcrowding, ill-ventilation, and indoor smoke are mentioned to be some of the risk factors for ARI (Pore et al. 2010). ARI is the main cause of mortality and mortality among newborns and young children (Wang et al. 2020a, b). The WHO has reported that $16 \%$ of deaths among children under-5 years were because of ARI in 2015. Additionally, ARI including pneumonia is a significant cause of substantial disease burden among adults equal to or older than 65 years (Shi et al. 2019). The diverse range of pathogens responsible for ARI, include viruses, bacteria, and fungal pathogens. Among them, viruses specifically RSVs are reported to be the main cause of severe ARI in preterm infants and they are at higher risk for the requirement of the intensive care unit (ICU) (Benítez-Guerra et al. 2020). It has been demonstrated that child and maternal age, residence, and maternal hand hygiene information can be important factors for the occurrence of ARI among children under-5 years (Dagne et al. 2020). On the other hand, some investigations were shown that RSV is also an important viral pathogen recognized in adult ARI patients. PCR, serological typing, bacterial culture, and antibody detection are reported to be the gold standards for diagnosis of ARI. However, there is a challenge to simultaneously recognize all potential pathogens for ARI and also capture new or uncommon respiratory pathogens (Wang et al. 2020a, b).

Viral respiratory infections

Viral respiratory tract infection can cause different ranges of disease syndromes from mild, predominant upper respiratory syndromes to pneumonia and bronchiolitis which are more severe forms. Despite this variety, viral infections of the respiratory tract may vastly lead to self-limiting and mild symptoms which last a few days. However, according to the epidemiological, clinical and experimental evidence, respiratory virus infections have been known to be the main inducers of acute exacerbations (AEs) in chronic lung disorders such as asthma, chronic obstructive pulmonary disease (COPD), and cystic fibrosis (CF) (Ritchie et al. 2017). RV, RSV, human metapneumovirus (HMPV), influenza virus, parainfluenza virus, adenovirus, human bocavirus ( $\mathrm{HBoV}), \mathrm{CoV}$, and enterovirus are kinds of viruses which are in the association with acute wheezing illness and also asthma exacerbations (Coverstone et al. 2019). RVs infection is associated with common cold characteristics, but it is not the only effect of RVs infection. They have effects on both upper and lower respiratory syndromes and it has been known that RVs have roles in exacerbations of cystic fibrosis in children and chronic bronchitis in adults (Turner 2007). RV and RSV have been mentioned to have a major role in acute lower respiratory tract infections in infants. Moreover, RSVs can lead to more severe forms than RVs in very young infants (Luchsinger et al. 2014). Influenza viruses and CoVs have led to many outbreaks of viral pneumonia worldwide and caused different effects (Cong 2019). Respiratory infections (caused by influenza and other respiratory viruses) commonly manifest as a mild illness, but these viruses have the potential to result in hospitalization and death (Jiang et al. 2017). ARI which mainly affects the upper tract exclusively, in a small percentage can progress to lower respiratory tract infections such as bronchiolitis and pneumonia in which children and elderly people are at higher risk. (van Doorn and Yu 2020). Bronchiolitis is a common and potentially life-threatening respiratory condition that affects young babies. The majority of infants who are admitted to hospital with bronchiolitis are infected with RSVs and all of them presents intensive inflammatory responses in their 
airways (Smyth and Openshaw 2006). The ARDS which is a clinical syndrome of acute lung disorder (Ware and Matthay 2000) and mainly caused by primary pneumonia (Matthay and Zemans 2011), and pneumonia itself (that can be linked to several viruses) (Ruuskanen et al. 2011) are going to be discussed further.

\section{Pneumonia}

By the increasing rate of immunosuppressive therapies, increased life span, the acquired immunodeficiency syndrome (AIDS) progression, etc. the number of people who are at the risk of viral pneumonia may be raised. Viral pneumonia refers to disease condition when there is viral causation of abnormalities in gas exchanges at the level of alveoli. Old age, viralbacterial co-infection, underlying malignancy, and shock at the initial presentation are some independent predictors which are associated with short-term mortality in adult patients with viral pneumonia. Moreover, there is a broad list of the differential diagnoses for viral pneumonia including bacterial pneumonia, bacterial or viral bronchitis, fungal pneumonia, lipoid pneumonia, sarcoidosis, amyloidosis, hyper-reactive airway disease, pulmonary hypertension, and some others (Freeman et al. 2019). Pneumonia is an important cause of death among young children and elderly people which is correlated with several pathogens especially viruses (Lin et al. 2019). Due to the progress of viral infection diagnosing methods, the viral cause of infection in pneumonia is frequently recognized as a cause of community-acquired pneumonia (CAP) in adults as well as pediatrics (Kim et al. 2019). Moreover, the effects of viruses on hospitalacquired pneumonia and ventilator-associated pneumonia are being investigated (Dandachi and Rodriguez-Barradas 2018). Herein, RSV, RV, influenza viruses (A, B, and C), parainfluenza viruses (type 1, 2, 3, and 4), enteroviruses, hantavirus, and CoVs are RNA viruses which are associated with pneumonia. On the other hand, adenovirus, varicella-zoster virus, parechovirus (HPeV), epstein-barr virus (EBV), herpes simplex virus (HSV), and cytomegalovirus (CMV) are DNA viruses which can cause pneumonia. The most common cause of viral pneumonia in small children is RSV and the virus which is associated with mortality and morbidity more than others is influenza A. Adenovirus has an important role in the causation of pneumonia in solid organ transplantation or hematological transplantation. CMV is an important cause of pneumonia in human immunodeficiency viruses (HIV) -infected subjects with CD4 counts lower than 100 cells $/ \mathrm{mm}^{2}$. (Freeman et al. 2019). Additionally, human coronaviruses (HCoVs) have been known to be important pathogens of respiratory tract infections; because of the outbreaks of SARS and MERS (Yin and Wunderink 2018). SARS and MERS are associated with severe pneumonia and the prognosis of infection with SARS and MERS is harder than RSV or influenza virus (Freeman et al. 2019). Pneumonia is also one of the typical clinical symptoms of the patients infected by 2019 novel CoV (2019-nCoV) (SARS-CoV-2). Progressive respiratory failure has been founded in this condition; new pulmonary infiltrates on chest radiography and no obvious improvement after antibiotic therapy for three days, have been also mentioned to be the criteria related to this disease (Zhou et al. 2020). Laboratory examination of complete blood count (CBC) with differential, chemistry panel, C-reactive protein (CRP), enzyme-linked immunosorbent assay (ELISA)—rapid antigen tests could be useful for the diagnosis of viral pneumonia. Furthermore, gene amplification, cytological evaluation, viral culture and viral antigens serology are also mentioned to be helpful diagnosis approaches in different capabilities. Although imaging features alone, are not able for diagnosing the pneumonia definitely, recognition of viral pneumonia patterns may be helpful to avoid unnecessary use of antibiotics (Koo et al. 2018). In the chest x-ray, interstitial infiltration and its patchy distribution and bilateral infiltrate are more suggestive of viral pneumonia (Freeman et al. 2019). Generally, laboratory findings, biomarkers, and radiographic patterns have not an ability for definite viral diagnosing; however, reverse transcription-polymerase chain reaction (RT-PCR) to detect viral nucleic acid in respiratory secretions, provides a manner that is done for laboratory confirmation (Dandachi and Rodriguez-Barradas 2018). One of the suggestive options for the treatment of viral pneumonia is supportive care which is included maintaining required oxygen, hydration, rest and increasing required calorie following higher respiratory effort. Besides, there are also some specific viral therapies and also prophylactic therapies (such as vaccination or specific immunoglobulins) for some of the viral pneumonia cases. Because of the frequent 
amount of evidence related to the coexisting bacterial types of pneumonia, appropriate treatment and management of comorbid illnesses are also important. (Freeman et al. 2019). It has been mentioned that there are also limited treatments and antiviral (available for immunocompromised subjects) therapies for noninfluenza pneumonia viruses (Dandachi and Rodriguez-Barradas 2018). In general, developing effective vaccines and treatment approaches, and more sensitive diagnostic tests for viral pneumonia is yet an important issue especially in high-risk adult patients (Kim et al. 2019).

\section{Acute respiratory distress syndrome}

ARDS is a clinical syndrome of acute respiratory failure and it is associated with arterial hypoxemia, dyspnea and presents with a highly increased work of breathing. Sepsis, pneumonia and major trauma are some of the clinical conditions which are connected to ARDS developing (Matthay and Zemans 2011). Symptoms and clinical presentations of ARDS are variable depends on the severity of the condition, and also nonspecific which overlaps with several other conditions. Nevertheless, respiratory distress (such as dyspnea and tachypnea) with lower arterial saturation of oxygen, epigastric pain, nausea, vomiting, fever, and hypotension are common symptoms. Further, in the early phases of ARDS, respiratory involvement might be the only sign of the disease (Virani et al. 2019). The characteristic pathological findings in the lungs of ARDS patients can be divided into three groups according to the phases of occurrence; in the acute phase which refers to the first 6 days, interstitial and alveolar edema with the accumulation of neutrophils, macrophages and red blood cells in the alveoli and also endothelial and epithelial injury could be founded. For the second week, which is termed subacute phase, reabsorption of edema, signs of repairing, infiltration of fibroblasts and collagen deposition could be mentioned. After those 14 days, in the chronic phase more mononuclear cells, more fibrosis and epithelial repairing, and the signs of resolution of the acute neutrophilic infiltrates could be seen (Fig. 1) (Matthay and Zemans 2011). ARDS as a clinical syndrome is presented by inflammatory pulmonary edema, severe hypoxia, and stiff lungs. Diffuse endothelial and epithelial injury is also mentioned to be its characteristics (Gattinoni et al.
2006). As it was mentioned, ARDS and also acute lung injury (ALL) might be associated with some clinical conditions and there are several causes for the occurrence of ALI/ARDS; pulmonary or non-pulmonary infection, severe sepsis, aspiration of gastric contents, hemorrhage and shock are some of them (Fig. 1). It is important to emphasize that some nonpulmonary organ failure such as cardiovascular failure, renal failure, liver function and hematologic abnormalities may be developed in patients with acute respiratory failure from ARDS (Matthay and Zemans 2011).

Numerous viruses have been reported that have an important role in the occurrence of pediatric ARDS. RSV and influenza A (sub type H1N1) virus are mentioned to be the most common viruses having roles in the etiology of the disease. The most common cause of pediatric ARDS is primary infection with or without systemic infection and seasonal viruses such as RSV, non-pandemic influenza, RVs, parainfluenza, adenovirus, CoVs, and HMPV (Nye et al. 2016). ARDS is an important and serious complication in patients infected by H1N1 virus (Ferrarini et al. 2017). Therefore, influenza infection could be followed by lower respiratory tract infections and even ARDS especially in adult immunocompromised hosts (Dioverti et al. 2016). SARS and MERS were reported to be the considerable causes of ARDS. A large percentage of patients infected with SARS, experienced severe complications, with $20 \%$ developing ARDS and in MERS patients, mild upper respiratory symptoms, severe pneumonia, ARDS and some other complications were reported (Nye et al. 2016). The infection with 2019-nCoV can also cause severe respiratory illnesses such as ARDS (Chen et al. 2020b). Besides, nosocomial infections (such as reactivation of latent $\mathrm{HSV}$ in adult patients with mechanical ventilation) are also important causes of respiratory disorders leading to ARDS in both children and adults (Nye et al. 2016). Several clinical trials and researches have been carried out to understand the epidemiology and pathogenesis and also to test new therapies for ARDS (Matthay and Zemans 2011). ARDS is known to be an important and costly public health problem. In some studies, it has been demonstrated that survivors of ARDS among relatively young patients, will suffer from limited persistent exercises and lower physical quality 5 years after their critical illness. These mentioned limitations impose 


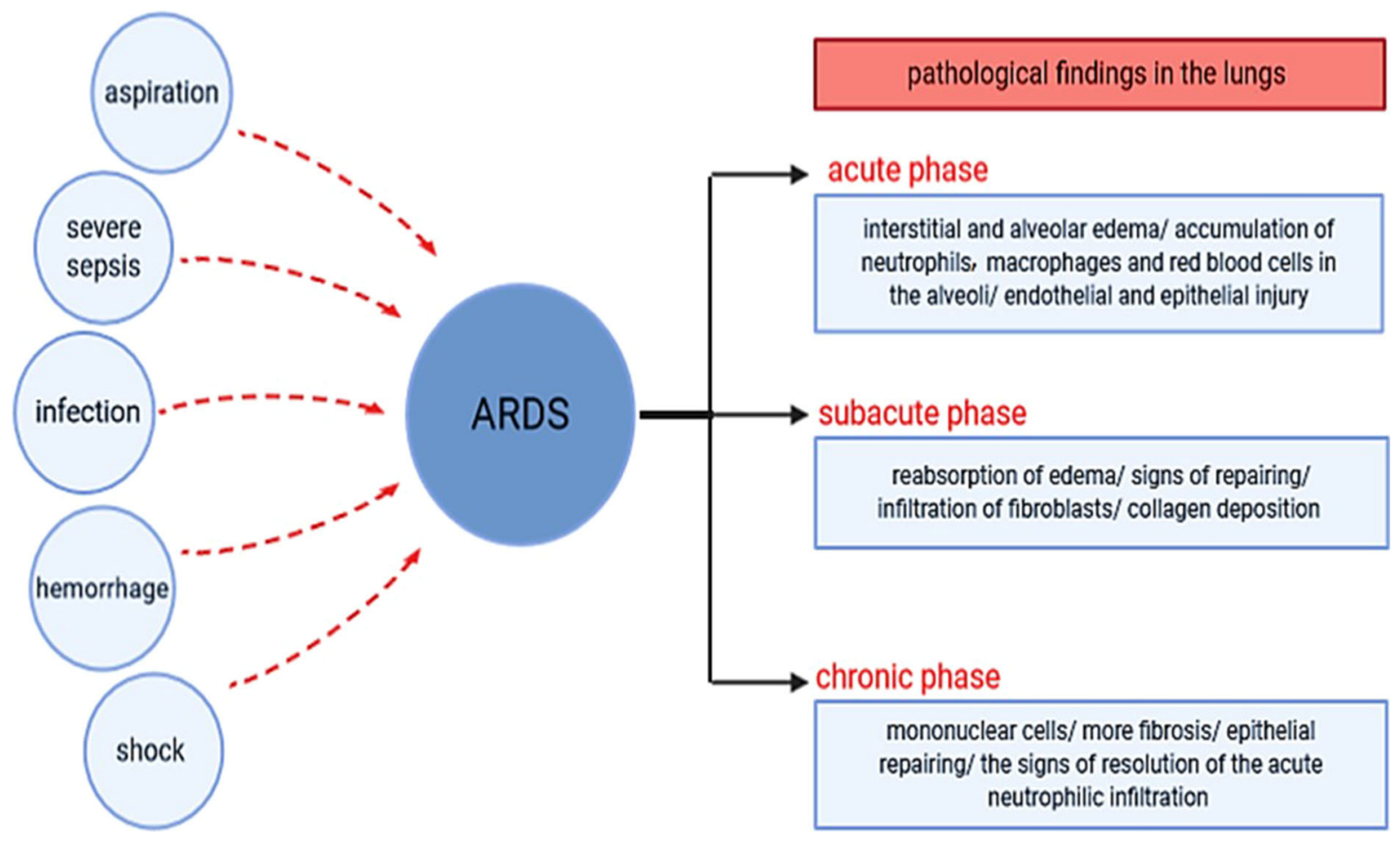

Fig. 1 Acute Respiratory Distress Syndrome (ARDS). Pulmonary or non-pulmonary infection, severe sepsis, aspiration of gastric contents, hemorrhage and shock are mentioned to be some of the causes for ARDS. Pathological findings of ARDS in lungs can be divided into three groups depending on the phase of occurrence; in the acute phase, interstitial and alveolar edema, accumulation of neutrophils, macrophages and red blood cells in

higher costs and use of health care services due to severe lung injury (Herridge et al. 2011). It has been founded that there are no pharmacological treatments to benefit ARDS patients and even they may lead to possible harms; however, lung-protective mechanical ventilation has been founded to be effective. Recent guidelines on mechanical ventilation in ARDS, may help clinicians to deliver interventions in an evidencebased manner that may lead to better outcomes (Fan et al. 2018). Mechanical ventilation which often used in patients with ARDS to restore required oxygen can lead to pulmonary damage itself; which is not distinguishable from those ARDS causes. This complication has altered the target of mechanical ventilation in patients with ARDS (which was the maintenance of normal gas exchange) and has shifted it to the protection of lung from the injuries caused by the ventilator (Gattinoni et al. 2006). Noninvasive ventilation (NIV) is a common and well-established the alveoli, endothelial and epithelial injury; in the subacute phase, reabsorption of edema, signs of repairing, infiltration of fibroblasts, collagen deposition and in chronic phase, more mononuclear cells, more fibrosis, and epithelial repairing and also the signs of resolution of the acute neutrophilic infiltration are the characteristics of findings in lungs (Matthay and Zemans 2011)

treatment used to prevent endotracheal intubation in patients with ARDS. It has been founded that patients with hypoxemic acute respiratory failure who succeed in an NIV trial, represent a better prognosis compared to those who failed. Higher ICU severity score, presence of severe sepsis and lower ratio of arterial oxygen tension to fraction of inspired oxygen are other factors that could be in the association with worse outcomes (Tucci et al. 2016).

\section{Common respiratory viruses}

$\mathrm{RV}$, RSV, HMPV, influenza virus, parainfluenza virus, adenovirus, $\mathrm{HBoV}, \mathrm{CoV}$ and human enteroviruses (HEV) can affect the respiratory tract and they are in the association with the acute wheezing illness (Coverstone et al. 2019). Adenoviruses, influenza types A and B, parainfluenza, and RSVs are common 
viral agents associated with respiratory infections and may lead to a different range of acute upper and lower respiratory tract diseases. They may be associated with serious clinical complications such as croup, bronchiolitis, and pneumonia especially in immunocompromised patients (Syrmis et al. 2004). In a study, it has been shown that respiratory viruses were highly detected in bronchoalveolar lavage fluid samples of $\mathrm{CF}$ patients and were in the association with markers of disease severity (Esther Jr et al. 2014). RSV is the most common virus recognized in young children with an acute lower respiratory infection and was related to 33.8 million new cases globally in 2005 (Shi et al. 2015). RSVs also have a close relation to severe lower respiratory illnesses which require hospitalization. $R V s$, in the first year of life are the major upper and lower respiratory pathogens (Kusel et al. 2006). It has been founded that RV infection is associated with $60-70 \%$ of the asthma exacerbations in school-aged children (Turner 2007). HMPV has been also known to be an important cause of severe respiratory diseases, particularly in infants, young children, and elderly people (Ditt et al. 2011). Human parainfluenza virus types $1,2,3$, and 4 have been recognized as respiratory pathogens in young children and their importance in adults has been also known (Hall 2001). Certain serotypes of adenoviruses have been mentioned to be the cause of epidemic pneumonia and other types of respiratory tract infections in closed communities (Lehtomäki et al. 1986). HEV can cause different clinical syndromes, such as mild upper respiratory tract illnesses and even severe and potentially fatal conditions. HEV-68/71/104, coxsackievirus A9 (CVA9)/A21/B2/B4 and echovirus 9/11/22 are different subtypes of HEV which have been isolated from respiratory samples (Lu et al. 2014). HBoV may infect all age groups and it has appeared that the virus has the ability to trigger chronic lung disease (Schildgen and Schildgen 2018). Influenza virus causes contagious and acute respiratory disease and attacks the host respiratory tract mucosa (Tamura and Kurata 2004). Influenza viruses and CoVs have led to many outbreaks of viral pneumonia worldwide (Cong 2019) and CoVs are important pathogens with different effects on the human body (Chen et al. 2020c). They are enveloped, non-segmented and positive-sense RNA viruses which can cause infection in respiratory, gastrointestinal, hepatic and central nervous systems of humans and many animals (Lin et al. 2019; Chen et al. 2020c). CoVs are the group of viruses belongs to Coronavirinae which is a subfamily of the Coronaviridae family and the other subfamily is Torovirinae. Coronaviridae itself is a family of Nidovirales (Fig. 2) (Fehr and Perlman 2015; Lin et al. 2019; Gu et al. 2020). Coronavirus particles which are main structural proteins are including spike (S), membrane (M), envelope (E) and nucleocapsid (N) (Fehr and Perlman 2015; Cong 2019). SARS as a human disease (caused by SARS-CoV) is associated with pneumonia and it led to more than 7900 patients across five continents (Guan et al. 2003). SARS spread through air-travel (Hilgenfeld and Peiris 2013) and the death rate of SARS was 9.6\% (Guo et al. 2020). Ten years after the SARS outbreak, another unknown coronavirus (MERS-CoV) caused severe pneumonia and renal failure with a high fatality rate (Hilgenfeld and Peiris 2013). It is believed that origination of the virus was bats; but also there was an intermediate host (Fehr and Perlman 2015). MERS-CoV led to approximately 2500 cases and 800 deaths (Cascella et al. 2020). Recently, a novel coronavirus has also emerged and caused an outbreak of unusual viral pneumonia (Chen et al. 2020c), which is going to be discussed, further in the next parts.

\section{Novel coronaviruses; Covid-19}

2019-nCoV was first found in China and Huanan Seafood Market in which livestock animals were also traded (Sahin et al. 2020). Results of virus genome sequencing and further analysis have reported bat as a suspected natural host of virus origin which might be transmitted by the means of unknown intermediate hosts and thus, results in infection in humans (Guo et al. 2020). On January 30, WHO announced the presentation of the $\mathrm{nCoV}$ and declared it as a public health emergency of international concern (PHEIC) and on February 11, named it as COVID-19 (Chen et al. 2020c). On February 28, WHO raised the threat to the CoV epidemic outbreak to the "very high" level (Cascella et al. 2020). COVID-19 spread rapidly from a city to the entire country in 30 days (Wu and McGoogan 2020) and now, several other countries including Hong Kong, Italy, Japan, Russia, Iran, United States, and more than twenty other countries have reported COVID-19. Droplets, respiratory secretions, and direct contact are three ways for spreading the COVID-19; however, the isolation of SARS-CoV- 


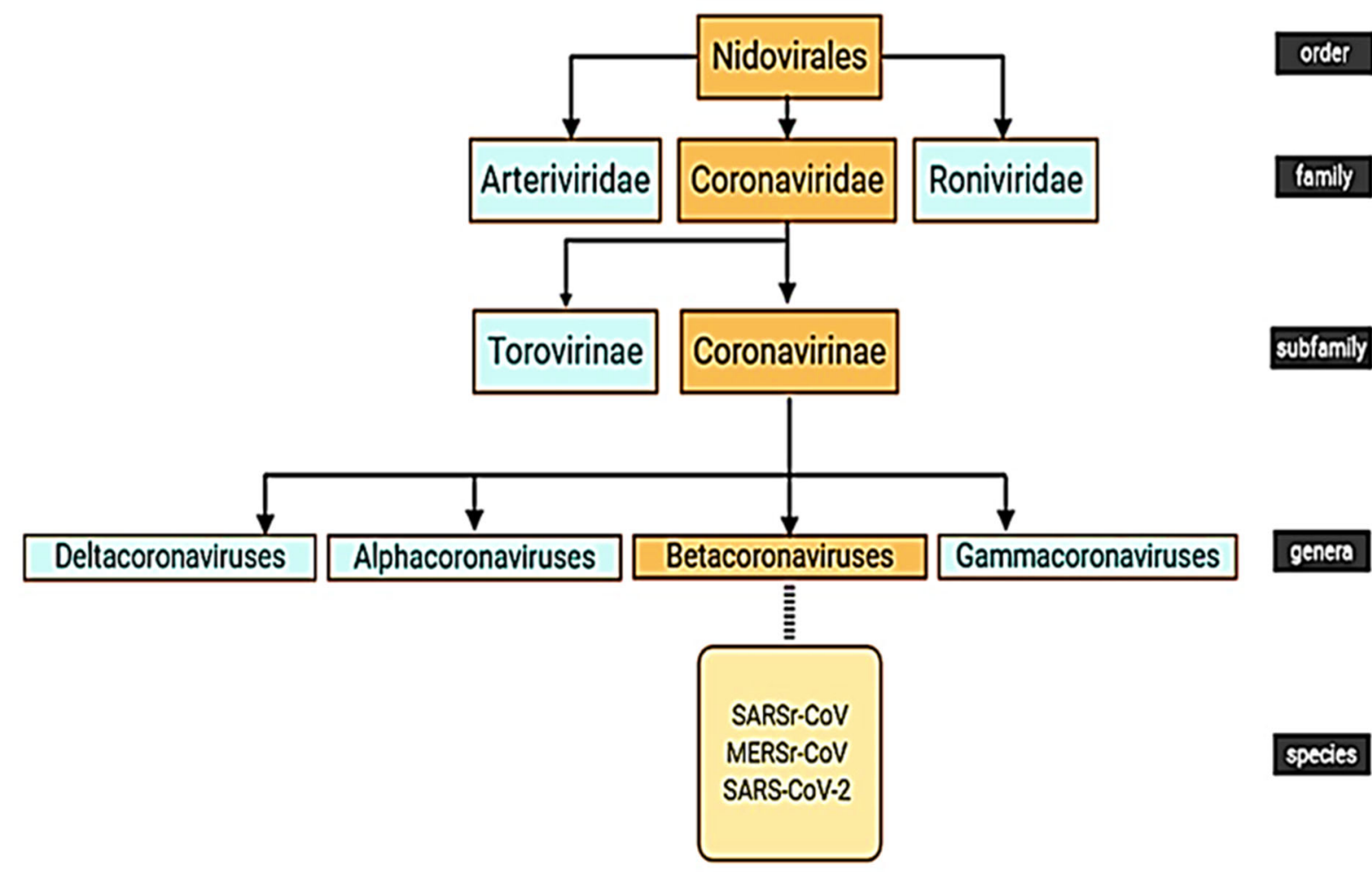

Fig. 2 Nidovirales Order. Nidovirales order contains three families: Arteriviridae, Roniviridae and Coronaviridae. Torovirinae and Coronavirinae are subfamilies of Coronaviridae and Coronavirinae includes four genera: Alphacoronaviruses, Betacoronaviruses, Gammacoronaviruses and

2 from fecal swabs of a severe pneumonia patient was also reported. The incubation period of the virus is mentioned to be 2-14 days and mostly 3-7 days in which the virus is contagious (Guo et al. 2020). On average, one patient infects 1.4-2.5 other persons (Javanian et al. 2019). Patients with cardiac diseases, hypertension or diabetes, who are treated with Angiotensin-converting enzyme 2(ACE2)-increasing drugs have been founded to be at higher risk for severe COVID-19 (Fang et al. 2020). In other words, based on studies higher concentrations of ACE2 can cause enhanced vulnerability to $2019-\mathrm{nCoV}$ in subjects who are using renin-angiotensin-aldosterone system inhibitors (Sama et al. 2020). There is also a particular risk for older persons for COVID-19 (Applegate and Ouslander 2020). Higher case fatality rate (CFR) has also observed in patients with chronic respiratory disease and cancer; but contrary to H1N1, pregnancy has not been appeared to be a risk factor for severe
Deltacoronaviruses (Fehr and Perlman 2015), which are subdivided into more subgenera (Lin et al. 2019). SARSr$\mathrm{CoV}, \mathrm{MERSr}-\mathrm{CoV}$ and SARS-CoV-2 are three species of Betacoronaviruses genera (Guo et al. 2020)

disease (Fisher and Heymann 2020). In addition, cancer receiving chemotherapy as well as multiple comorbidities can be a risk factor for severe illness (Aslam and Mehra 2020). It has been founded that the COVID-19 outbreak increased the risk of schizophrenia in older adults and also age is presented as an important risk factor for new schizophrenia caused by COVID-19 (Hu et al. 2020). The results of a research have been demonstrated that the prevalence of posttraumatic stress symptoms (PTSS) in China hardesthit areas was $7 \%$ one month after the outbreak which was higher in women and this presents the need for professional and effective mental health services (Chen et al. 2020c). Covid-19, as well as SARS and MERS, presents with cough and fever commonly and frequently followed by lower respiratory tract disease with poor clinical outcomes associated with older age and also underlying health conditions (Wu and McGoogan 2020). Common symptoms are fever, 
cough, and shortness of breath (Javanian et al. 2019); but the infection varies from asymptomatic or paucisymptomatic forms to clinical conditions associated with the requirement of mechanical ventilation and support in ICU and even to multiple organ dysfunction syndromes (MODS) and fatal cases. Clinical manifestations can be divided into three groups due to their severity according to Chinese centers for disease control (CDC) reports. In mild disease which includes $81 \%$ of cases, non-pneumonia and mild pneumonia could be predicted. The severe disease occurs in $14 \%$ of cases and includes dyspnea, respiratory frequency $\geq 30 / \mathrm{min}$, blood oxygen saturation $\left(\mathrm{SpO}_{2}\right)$ $\leq 93 \%$. $\mathrm{PaO} 2 / \mathrm{FiO}_{2}$ ratio $<300$ [(partial pressure of oxygen, $\mathrm{PaO}_{2}$ ) and (fraction of inspired oxygen, $\left.\mathrm{FiO}_{2}\right)$ ], and/or lung infiltrates $>50 \%$ within $24-48 \mathrm{~h}$ are other clinical manifestations of severe form of the disease. In critical disease which contains $5 \%$ of cases, respiratory failure, septic shock, and/or MOD or multiple organ failure (MOF) are clinical manifestations (Cascella et al. 2020). It has been also mentioned that mild, moderate, or severe illness may be the three presenting forms of COVID-19. Severe pneumonia, ARDS, sepsis, and septic shock are included in severe clinical manifestations. Mild fever, cough (dry), sore throat, nasal congestion, malaise, headache, muscle pain, or malaise in uncomplicated illness, cough and shortness of breath in moderate pneumonia, and fever with severe dyspnea, respiratory distress, tachypnea and hypoxia in severe pneumonia have been mentioned to be among clinical manifestations (Cascella et al. 2020). Some similarities have been observed between COVID-19 and influenza and also seasonal allergies (pollen allergies) in their signs and symptoms. For instance, they may also exhibit temperature. Thus, a diagnostic kit or meter is needed to detect patients accurately and rapidly (Shereen et al. 2020). So far, detecting nucleic acid in the respiratory tract samplings (for instance, nasal and throat swab sampling) by real-time PCR is a golden clinical method for diagnosis which further confirmed by next-generation sequencing (Guo et al. 2020). Although this nucleic acid testing is required to confirm the infection, symptoms, exposures, and chest imaging are also used for clinical diagnosis (Wu and McGoogan 2020). Generally, controlling the source of infection, early diagnosis, reporting and isolation along with good personal hygiene, fitted masks, ventilation, and avoiding crowded places will be helpful for the prevention of the disease (Chen et al. 2020c).

\section{Novel corona virus mechanism of action}

The genome of SARS-CoV-2 has shown over $80 \%$ similarity to other human CoVs and the entry mechanism is also as same as SARS-CoV. The structural proteins of SARS-CoV-2 are encoded by S, E, N and $\mathrm{M}$ genes which were presented earlier. Proteins needed for viral replication, nucleocapsid and spikes formation are encoded by specific genes in open reading frame (ORF1) downstream which are included in all CoVs (Shereen et al. 2020). A frameshift between ORF1a and ORF1b has a role in producing pp1a and pp1ab polypeptides, and also papain-like proteases to produce 16 non-structural proteins (nsps). It has been known that the function of the nsps and structural proteins have a connection to pathophysiology and virulence mechanisms of SARS-CoV-2 and other CoVs (Cascella et al. 2020). SARS-CoV-2 uses the same cell receptor ACE2 to SARS-CoV (Shereen et al. 2020). ACE2 has been found in the lower respiratory tract of humans and had a role in regulating the cross-species and human-to-human transmission in SARS-CoV patients. The bronchoalveolar lavage fluid sample from a patient with COVID-19 demonstrated that SARS-CoV-2 uses the same receptor to infect humans (Guo et al. 2020). It has been known that cigarette smoking can induce increased ACE2 in the respiratory tract and this reveals that cigarette smokers are more susceptible to COVID-19 (Wang et al. 2020a, b). Analyses have shown that ACE2 expression in kidney cells was not lesser than in lung, esophagus, small intestine and colon. It indicates that the kidney may be an important target for SARS-CoV2 (Xu et al. 2020). The life cycle of SARS-CoV-2 is initiated when $\mathrm{S}$ protein binds to the cellular receptor ACE2 that plays as a key receptor. Conformation change in the $S$ protein, viral envelope fusion with the cell membrane and releasing RNA into the host cell are included in the next steps. Subsequently, viral replicase polyproteins ppla and $1 \mathrm{ab}$ are originated by the translation of RNA genome and then they are cleaved into small products by viral proteinases. Production of sub-genomic messenger RNA (mRNA) and then relevant viral protein, assembling of viral proteins and genome RNA, and formation of the virions are the next phases of the life cycle. Virions are 
assembled in the endoplasmic reticulum (ER) and Golgi, and eventually they are released out of the cell (Shereen et al. 2020). Histological examination on the biopsy samples taken from a patient with COVID-19 showed bilateral diffuse alveolar damage with cellular fibromyxoid exudates. Desquamation of pneumocytes and formation of the hyaline membrane in the right lung, suggested the diagnosis of ARDS, while pulmonary edema with hyaline membrane formation in the left lung, indicated early-phase ARDS. Moreover, the rapid progression of pneumonia has been observed on X-ray images. Moderate micro-vesicular steatosis and mild lobular and portal activity have been founded in liver biopsy of the patient which may be caused by the means of SARS-CoV-2 infection or drug-induced liver injury. No histological changes were founded in the heart. Lymphopenia was also appeared in this patient (Xu et al. 2020). The Results of more researches showed that most of the patients with COVID-19, had decreased white blood cell counts and lymphocytopenia; however, neutrophil count, D-dimer, blood urea, and creatinine levels were considerably higher in severe patients and decreased counts of lymphocyte were founded continuously. Increased levels of interleukin (IL)-6, IL-10, and tumor necrosis factor- $\alpha$ (TNF- $\alpha$ ) as inflammatory factors with the higher plasma levels of IL-2, IL-7 and some other inflammatory factors in ICU patients, were also seen (Guo et al. 2020). Lymphopenia has been founded to be a negative prognostic factor (Cascella et al. 2020). Increased incidence of acute renal injury was reported (that can occur because of SARS-CoV-2) along with the inflammation induced by the disease or the effect of both of them on kidneys (Rismanbaf and Zarei 2020). Hospitalized COVID-19 patients have been shown higher levels of kidney impairments such as hematuria, proteinuria, and kidney dysfunction and it has been known that there is a correlation between indicators of kidney impairments and the higher risk of in-hospital death (Cheng et al. 2020). Cytokine storm syndrome may lead to hepatic injury in patients with COVID-19 and a positive correlation has been seen between liver injury and an increased level of CRP. Higher levels of lactate dehydrogenase (LDH) and liver and muscle enzymes may be also found (Cascella et al. 2020). Therefore, SARS-CoV-2 can lead to liver damage and Lopinavir/ritonavir should be carefully used for the treatment of patients with COVID-19; because of the connection seen between emerging liver injury after admission and their application (Fan et al. 2020). It has been stated that liver injury is more common in severe cases of COVID-19 compared to mild cases (Xu et al. 2020). In a retrospective study on 121 symptomatic patients, bilateral and peripheral ground-glass and consolidative pulmonary observed on computed tomography (CT) scan, were known to be the hallmarks of COVID-19 infection. $56 \%$ of early patients have shown a normal CT scan; but it has been demonstrated that there is a relation between the frequency of CT findings and infection time course. After a longer time with the appearance of symptoms, more findings can be seen on CT scan. Consolidation, bilateral and peripheral disease, greater total lung involvement, linear opacities, "crazy-paving" pattern and the "reverse halo" sign are meant to be these findings. $28 \%$ of early patients, $76 \%$ of intermediate patients and $88 \%$ of late patients were shown bilateral lung involvement. (Bernheim et al. 2020). There are several CT features such as linear opacities, crazypaving patterns, bronchial wall thickening, high CT scores and extra-pulmonary lesions which are associated with severe/critical form of COVID-19 pneumonia (Shereen et al. 2020). In another study it has been demonstrated that the highest severity of lung disease was observed on CT about10 days after onset of symptoms. After 14 days from the initial onset of symptoms which was named the absorption stage, signs of improvement can be seen (Pan et al. 2020). Covid-19 is never just confined to respiratory damage. Patients with signs of cardiac injury should also be identified earlier; because heart injury signs are increased in COVID-19; especially in patients who are male, older, smoker and also in hypertension cases (Wu et al. 2020).

\section{Inflammatory process of acute respiratory infections caused by COVID-19}

Severe pneumonia, ground-glass opacities, and acute cardiac injury are the main pathogenic incidences of COVID-19 infection by the target of the respiratory system. Multiple peripheral ground-glass opacities in sub-pleural regions of both lungs in some patients may cause higher inflammation due to induced immune response. Higher leukocyte numbers and increased blood levels of cytokines and chemokines as inflammatory factors are also reported in patients infected 
with COVID-19 including IL1- $\beta$, (IL1recepotor agonist) IL1RA, IL7, IL8, IL9, IL10, basic fibroblast growth factor (FGF2), granulocyte colony-stimulating factor (GCSF), granulocyte-macrophage colony-stimulating factor (GMCSF), interferon gamma (IFN $\gamma$ ), IFN $\gamma$-induced protein10 (IP10), monocyte chemoattractant protein-1 (MCP1), macrophage inflammatory protein $1 \alpha$ (MIP1 $\alpha)$, MIP1 $\beta$, platelet-derived growth factor subunit B (PDGFB), TNF $\alpha$, and vascular endothelial growth factor (VEGF). Levels of proinflammatory cytokines such as IL2, IL7, IL10, GCSF, IP10, MCP1, MIP1 $\alpha$, and TNF $\alpha$ were reported to be higher in some of the patients hospitalized in ICU and these levels had an association with promoted disease severity (Rothan and Byrareddy 2020). In a case report study, reduced numbers of peripheral CD4 and CD8 with their hyper-activated status (high proportions of HLA-DR (CD4 3.47\%) and CD38 (CD8 39.4\%) double-positive fractions) were founded in a patient infected with COVID-19. The higher concentration of pro-inflammatory chemokine receptor $(\mathrm{CCR}) 6+\mathrm{T}$ helper (Th) 17 in CD4 T and increased concentrations of cytotoxic granules in CD8 $\mathrm{T}$ cells were also reported. Tissue samples taken from both lungs of the patient demonstrated interstitial mononuclear inflammatory infiltration (lymphocytes dominated) (Xu et al. 2020). It has been mentioned that total $\mathrm{T}$ cells, CD8 $+\mathrm{T}$ cells and CD $4+\mathrm{T}$ cells count lower than $800 / \mu \mathrm{L}, 300 / \mu \mathrm{L}$, and $400 / \mu \mathrm{L}$ in non-ICU patients, reveals the continues requiring of aggressive intervention even in immediate absence of more severe symptoms; because their condition has a higher risk for getting worse (Diao et al. 2020). In a study, it has been mentioned that IL2 receptor $>793.5 \mathrm{U} / \mathrm{mL}$, CRP $>30.7 \mathrm{ng} / \mathrm{mL}$, white blood cells $>9.5 \times 10^{9} \mathrm{~L}$ or neutrophil count $>7.305 \times 10^{9} \mathrm{~L}$ are among the parameters which should be observed accurately to follow the progression of COVID-19 to the critical stage. There is a close correlation between the severity of the disease and inflammation; therefore, IL-6, TNF $\alpha$ and IL- 8 might be beneficial to be the promising therapeutic targets (Gong et al. 2020). In the other study, it has been known that there is a positive correlation between CT imaging score and severity of the disease. Based on CT imaging score, the higher levels of enzymes, coagulation-related indicators and inflammation markers were shown in patients with increased CT imaging score. These indicators were IL6, CRP, erythrocyte sedimentation rate (ESR), serum amyloid A (SAA), Serum ferritin, aspartate aminotransferase (AST), LDH, $\alpha$-hydroxybutyrate dehydrogenase, D-dimer and fibrinogen (FIB) which are useful to monitor the progression of COVID-19 and also its prognosis. Additionally, the linear correlation was also seen between the levels of IL-6, CRP, LDH, AST, D-dimer and FIB as prominent indicators, and CT imaging score (Wang et al. 2020a, b). During SARSCoV-2 infection, some host immune responses and viral-host interactions occur. ACE2 expressing target cells such as alveolar type 2 cells are infected because of aerosolized uptake of SARS-CoV-2. Decreased anti-viral IFN responses due to the presence of virus, causes viral replication. Moreover, the influx of neutrophils and monocytes/macrophages may lead to hyper-production of pro-inflammatory cytokines (cytokine storms) and may result in the immunopathology of lung. Inducing the specific Th1/Th17 associated with exacerbation of inflammatory responses and the production of specific antibodies from B-cells/plasma cells to neutralize viruses are also other interactions (Fig. 3) (Prompetchara et al. 2020).

According to researches about previous CoVs, it has been mentioned that innate immunity has an important role in protective or destructive responses and may provide hopes for bringing new treatment options by the means of immune intervention. Hyperproduction type I IFN and the influx of neutrophils and macrophages as important sources of pro-inflammatory cytokines caused by active viral replication. SARS-CoV-2 may probably induce delayed-type I IFN and loss of viral control in an early phase. Patients with underlying diseases are more susceptible to COVID-19, while young children showed no severe cases. Indeed, in young children the innate immune response is highly effective that may reveal the key role of innate immunity (Prompetchara et al. 2020). As it was mentioned before, the functions of the nsps and structural proteins have effects on the pathophysiology and virulence mechanisms of $\mathrm{CoVs}$ and also SARSCoV-2 as an example. nsp has the ability to block host innate immune response (Cascella et al. 2020). It has been also mentioned that the high ability of contagious in SARS-CoV-2 is in association with the stabilizing mutation falling in the endosome-associated-proteinlike domain of the nsp2 protein (Angeletti et al. 2020). ARDS is reported to be the main cause of death in COVID-19 patients and in a study, six patients died because of ARDS out of 41 patients who were 


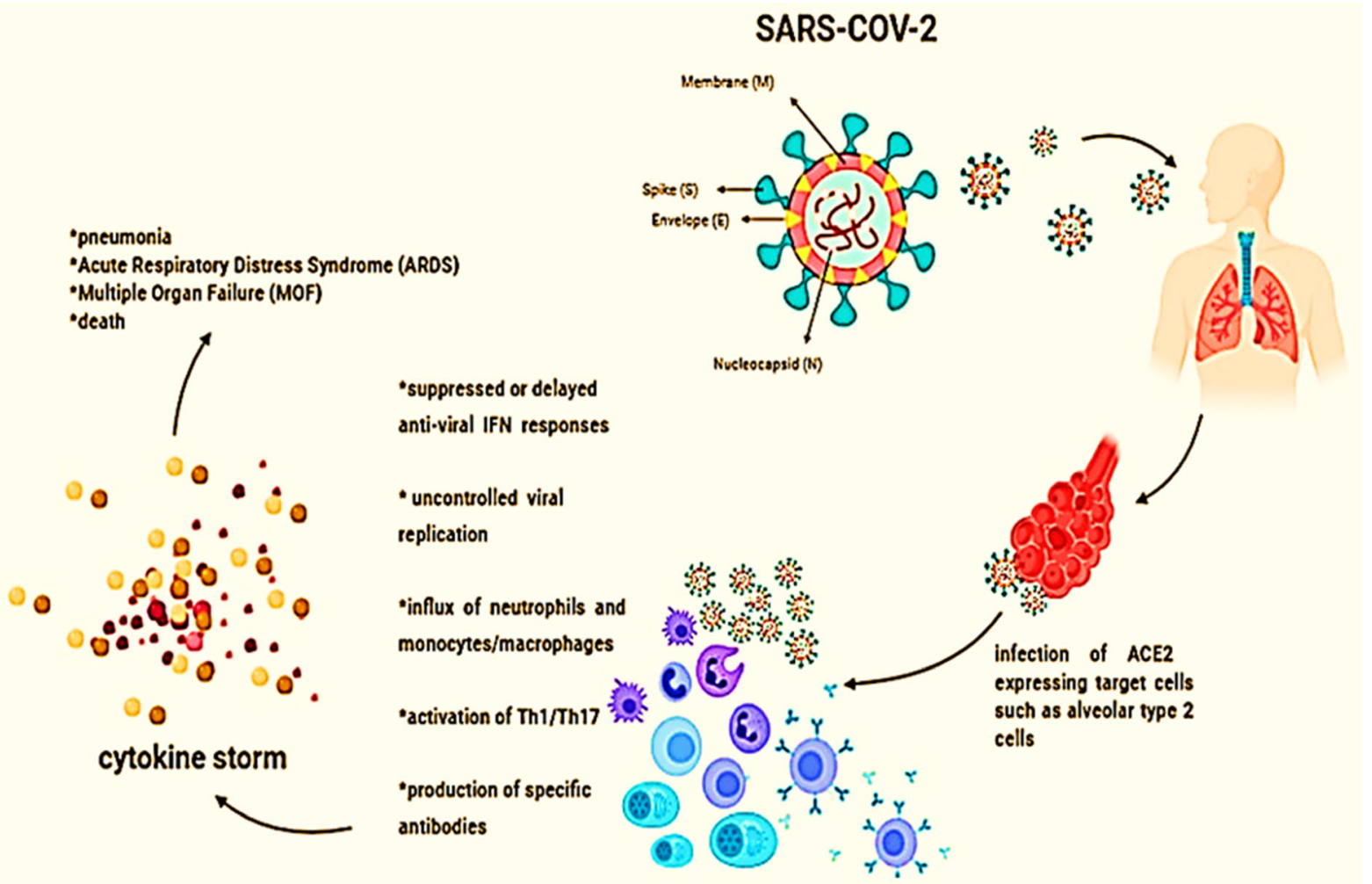

Fig. 3 Inflammatory Process of Acute Respiratory Infections Caused by COVID-19. Coronavirus particles containing spike $(\mathrm{S})$, membrane $(\mathrm{M})$, envelope $(\mathrm{E})$ and nucleocapsid $(\mathrm{N})$ are $\mathrm{CoVs}$ main structural proteins (Fehr and Perlman 2015). Aerosolized uptake of SARS-CoV-2, infection of Angiotensin-converting enzyme 2 (ACE2) expressing target cells such as alveolar type 2 cells, delayed or suppressed Type I interferon (IFN) responses, viral replication, the influx of neutrophils and monocytes/macrophages, activation of $\mathrm{T}$ helper1/17 (Th1/

admitted in the early stages of the outbreak. Deadly and uncontrolled systemic inflammatory responses by the means of releasing the large amounts of proinflammatory cytokines (IFN- $\alpha$, IFN- $\gamma$, IL-1 $\beta$, IL-6, IL-12, IL-18, IL-33, TNF- $\alpha$, transforming growth factor beta (TGF- $\beta$ ), and etc.) and chemokines (CCL2, CCL3, CCL5, CXCL8, CXCL9, CXCL10, etc.) is an important mechanism for ARDS. Therefore, the cytokine storm may cause ARDS, MOF and eventually death in severe cases of COVID19 (Fig. 3) (Cheng et al. 2020). Generally, all patients should be monitored for hyper-inflammation findings to recognize patients in which immunosuppression might have beneficial effects (Mehta et al. 2020).
Th17) associated with exacerbation of inflammatory responses, production of specific antibodies from B-cells/plasma cells and hyperproduction of pro-inflammatory cytokines called "cytokine storms" (which leads to the immunopathology of lung) are the major viral-host Interactions (Prompetchara et al. 2020). The cytokine storm might lead to acute respiratory distress syndrome (ARDS), multiple organ failure (MOF) and eventually death in severe cases of COVID-19 (Cheng et al. 2020)

\section{Appropriate treatments for acute respiratory infections caused by COVID-19}

According to studies, subjects with mild levels of the COVID-19 do not need hospitalization and can be treated using oxygen therapy, external cooling, acetaminophen, and nutritional supplements (Hassan et al. 2020; Organization 2020). However, individuals with severe levels of COVID-19 who exhibit severe ARIs and various degrees of respiratory syndromes, are required fundamental care and hospitalization (Organization 2020; Stoecklin et al. 2020). In this context, some fundamental cares are included: HFNOT which may prevent or delay the intubation requirement, tidal volume strategy of 4 to $6 \mathrm{~mL} / \mathrm{kg}$ predicted body weight, maintaining the plateau airway 
pressure less than $30 \mathrm{~cm}$ water, PEEP, RMs, using neuromuscular-blocking agents (for patient-ventilator dyssynchrony (PVD), increased airway pressure, and hypoxemia situation), prone positioning (for worsening hypoxemia), administration of 5-20 ppm ofi nhaled NO, fluid management (for a negative fluid balance), renal replacement therapy (Its beneficial effects on oxygen delivery and survival have been shown in individuals with ARDS), and ECMO(should be considered using the EOLIA trial criteria) (Matthay et al. 2020; Organization 2020). On the other hand, empiric antibiotic therapy for probable bacterial coinfection and using convalescent plasma (obtained from recovered COVID-19 subjects) are suggested (Murthy et al. 2020). Additionally, based on some evidence it was noted that in the case of viral pneumonia and ARDS, using glucocorticoids should be avoided (Matthay et al. 2020; Organization 2020). Moreover, alongside the mentioned therapies, a great deal of attention is now being paid to the application of regenerative medicine approaches.

Importance of cell therapy and regenerative medicine

Over recent years, investigations were indicated regenerative medicine can be paved the road for the treatment of many life-threatening diseases. In other words, translational cell biology can be considered as an innovative and efficient healthcare intervention for the promotion of the quality of life and medical costs reduction (Goodarzi et al. 2014, 2015; Payab et al. 2018, Baradaran-Rafii et al. 2020; Larijani et al. 2020). Herein, the great discoveries have highlighted that MSCs as regenerative medicine soldiers have long been regarding, based on their multi-potential differentiation capacity and self-renewal ability along with immunomodulatory potency. (Fitzsimmons et al. 2018; Goodarzi et al. 2018a, b). For instance, some investigations were shown that there is a higher survival rate in the subjects with H7N9 influenza who received MSC therapies compared to control group (Singh et al. 2020). Accordingly, MSC-based therapies also appear to be effective in eradicating severe ARIs caused by COVID- 19 .
Mechanism of mesenchymal stem cells-based therapies to attenuate inflammatory processes in acute respiratory infections caused by COVID-19

Since respiratory infections can damage the epithelial and immune cells of the lung and following that lead to no appropriate immune system function and ongoing inflammation, there is a need to be some contributing factors to reduce inflammation and repair damaged cells (Robb et al. 2016; Crane et al. 2018). In this respect, MSCs which have the potential to regulate proper proliferation and activation of immune cells along with differentiation into type II alveolar epithelial (ATII) cells (which form approximately $60 \%$ of the pulmonary alveolar epithelium) can be a contributing factor (Gotts and Matthay 2011; Harrell et al. 2019a, b, c). The mechanism of MSC activity may be via cell-to-cell communication and releasing extracellular vesicles (EVs) contains immunomodulatory molecules and cytokine (Lee et al. 2009; Huh et al. 2018; Harrell et al. 2019a, b, c; Martin-Rufino et al. 2019). Hereupon, MSCs can release prostaglandin E2(PGE2) (to induce production of anti-inflammatory cytokines from macrophages along with suppressing ongoing $\mathrm{T}$ cell-dependent inflammation), transforming growth factor beta (TGF- $\beta$ ), NO, and indoleamine 2,3-dioxygenase (IDO)( to inhibit ongoing $\mathrm{T}$ celldependent inflammation), induce the proliferation of regulatory $\mathrm{T}$ cells (to inhibit proliferation and activation of effector T-cells), increase the phagocytic activity of neutrophil, promote the macrophages differentiation into the M2 phenotype (for producing anti-inflammatory cytokines), inhibit neutrophil intravasation and pro-inflammatory activation by TGF- $\beta$. Collectively, MSCs are created an antiinflammatory environment for improving pathological resolution, function restoration, and tissue repair in the alveolar space) (Fig. 4) (English et al. 2008; Ma and Chan 2016; Wang et al. 2018; Weiss and Dahlke 2019; Jiang and $\mathrm{Xu}$ 2020). On the other hand, MSCs can transfer mitochondria to the damaged alveolar epithelium, increase the concentration of alveolar ATP, regenerate alveolar bioenergy, and finally lead to ameliorating function of the lung (Islam et al. 2012, Monsel et al. 2014). 


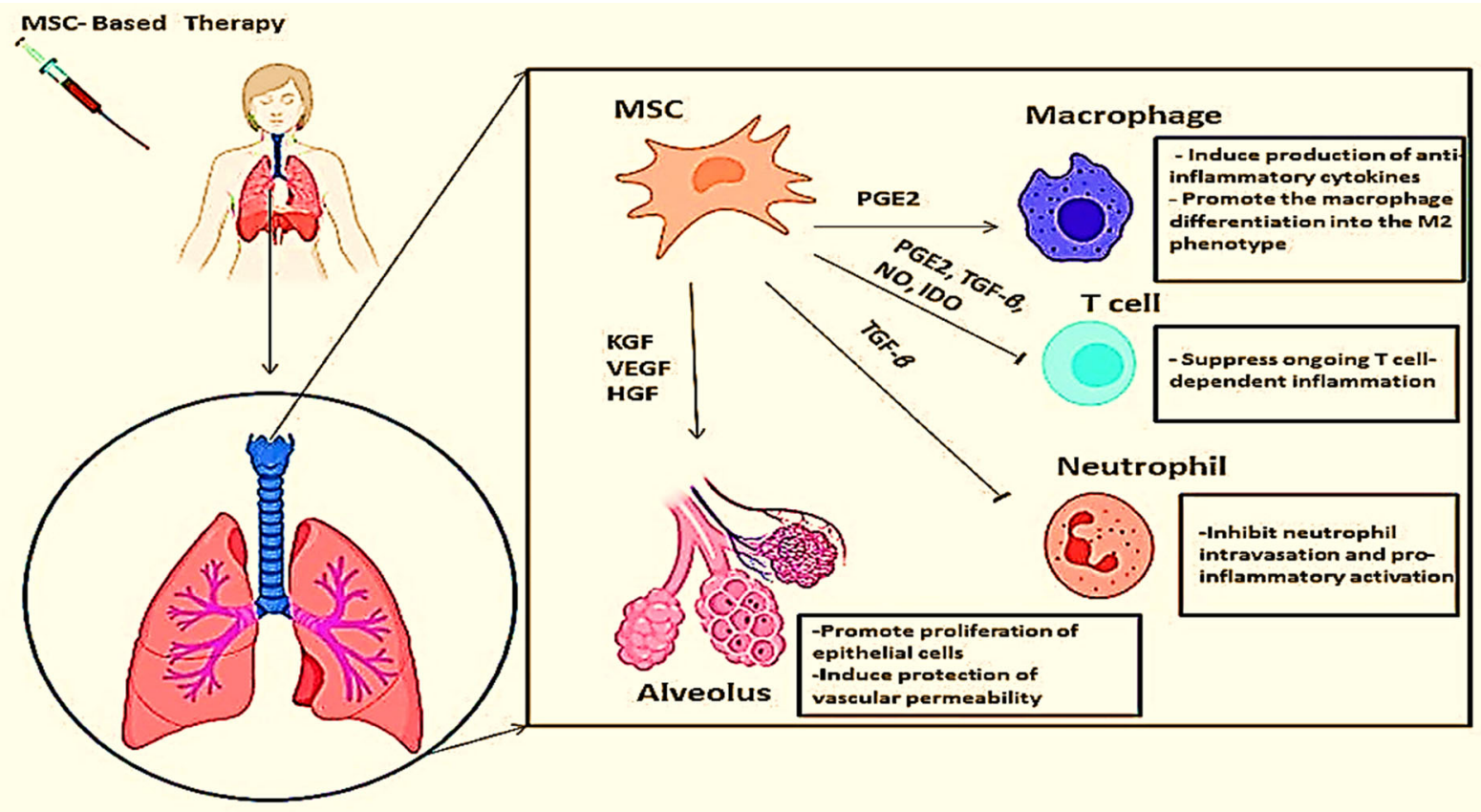

Fig. 4 Effects of mesenchymal stem cells on lung in acute respiratory infections caused by COVID-19 based on cell-to-cell communication and releasing immunomodulatory molecules. Mesenchymal stem cells (MSCs) can release prostaglandin E2(PGE2) to provoke the generation of anti-inflammatory cytokines from macrophages and inhibiting ongoing $\mathrm{T}$ celldependent inflammation, transforming growth factor-beta (TGF- $\beta$ ), nitric oxide (NO), and indoleamine 2,3-dioxygenase (IDO) to suppress ongoing $\mathrm{T}$ cell-dependent inflammation,

\section{Conclusion and future perspectives}

As life-threatening communicable diseases are accountable for the considerable worldwide burden of premature death and disability, discovering the best approaches to manage and eradicate them is a challenging issue. In the current state, COVID-19 (with related severe ARIs) is one of the rapidly expanding life-threatening communicable diseases around the world. Therefore, many steps have been taken and various plans have been devised to control and treat it. However, there is still no specific treatment and vaccine for COVID-19 and the presently approved treatments only can relieve symptoms. Indeed, COVID-19 treatment primarily depends on the patient's immune system. The excessive response of the immune system to kill the virus can lead to the production of numerous inflammatory factors including severe cytokine storm. Accordingly, it can cause organ destruction followed by ARDS, support the macrophages differentiation into the M2 phenotype for providing anti-inflammatory cytokines, suppress neutrophil intravasation and pro-inflammatory activation by TGF- $\beta$. Promote proliferation of epithelial cells and induce protection of vascular permeability by releasing keratinocyte growth factor (KGF), vascular endothelial growth factor (VEGF), and hepatocyte growth factor (HGF) (Wang et al. 2016; Harrell et al. 2019a, b, c; Caretti et al. 2020)

dysfunction of air exchange, acute cardiac injury, edema, and secondary infection that finally can lead to death (McGonagle et al. 2020). Herein, the prevention of a cytokine storm and controlling the inflammation can play a key role in the treatment of COVID-19. In this sight, several clinical trials have been operated globally to evaluate the effectiveness of different treatment options specifically MSC-based therapies as promising therapeutic strategies (Table 2). MSCs are proper therapeutic tools for severe ARIs (in COVID19 cases) by facilitating the lung tissue repair through the release of paracrine-soluble agents (that interact with immune cells) and their multipotent differentiation ability along with regenerating alveolar bioenergy. However, more investigations with a long follow-up period are demanded to increase the therapeutic outcome of MSCs besides creating the best strategy for application of them, including the best route and dose of administration. In this respect, further studies also should be performed on the use of 
Table 2 Cell- based Clinical Trials for COVID-19 Cases (https://clinicaltrials.gov/)

\begin{tabular}{|c|c|c|c|c|}
\hline Clinical trial title & Cell type & $\begin{array}{l}\text { Number of } \\
\text { participants }\end{array}$ & $\begin{array}{l}\text { Recruitment } \\
\text { status }\end{array}$ & Identifier number \\
\hline $\begin{array}{l}\text { Treatment of COVID-19 Patients Using } \\
\text { Wharton's jelly Mesenchymal Stem Cells }\end{array}$ & $\begin{array}{l}\text { Umbilical cord Wharton's } \\
\text { jelly-derived human } \\
\text { Mesenchymal stem cells }\end{array}$ & 5 & Recruiting & NCT04313322 \\
\hline $\begin{array}{l}\text { A Phase I/II Study of Universal Off-the-shelf } \\
\text { NKG2D-ACE2 CAR-NK Cells for Therapy of } \\
\text { COVID-19 }\end{array}$ & NK cells & 90 & Recruiting & NCT04324996 \\
\hline $\begin{array}{l}\text { Safety and Efficacy of Allogeneic Human Dental } \\
\text { Pulp Mesenchymal Stem Cells to Treat Severe } \\
\text { COVID-19 Patients }\end{array}$ & $\begin{array}{l}\text { Allogeneic Human Dental Pulp } \\
\text { Mesenchymal Stem Cells }\end{array}$ & 20 & Recruiting & NCT04336254 \\
\hline $\begin{array}{l}\text { NestCell }{ }^{\circledR} \text { Mesenchymal Stem Cells to Treat } \\
\text { Patients With Severe COVID-19 Pneumonia }\end{array}$ & $\mathrm{NestCell}^{\circledR}$ & 66 & Not Recruiting & NCT04315987 \\
\hline $\begin{array}{l}\text { Novel Coronavirus Induced Severe Pneumonia } \\
\text { Treated by Dental Pulp Mesenchymal } \\
\text { Stem Cells }\end{array}$ & $\begin{array}{l}\text { Dental Pulp Mesenchymal } \\
\text { Stem Cells }\end{array}$ & 24 & Not Recruiting & NCT04302519 \\
\hline $\begin{array}{l}\text { Treatment With Mesenchymal Stem Cells for } \\
\text { Severe Coronavirus Disease 2019(COVID-19) }\end{array}$ & Mesenchymal Stem Cells & 90 & Recruiting & NCT04288102 \\
\hline $\begin{array}{l}\text { Clinical Research of Human Mesenchymal Stem } \\
\text { Cells in the Treatment of COVID-19 } \\
\text { Pneuminia }\end{array}$ & $\begin{array}{l}\text { Umbilical Cord Mesenchymal } \\
\text { Stem Cells }\end{array}$ & 30 & Recruiting & NCT04339660 \\
\hline CAP-1002 in Severe COVID-19 Disease & $\begin{array}{l}\text { CAP-1002 Allogeneic Cardio } \\
\text { sphere Derived Cells }\end{array}$ & - & Available & NCT04338347 \\
\hline $\begin{array}{l}\text { ASC Therapy for Patients With Severe } \\
\text { Respiratory COVID-19(ASC COVID-19) }\end{array}$ & $\begin{array}{l}\text { Allogeneic Adipose Tissue } \\
\text { Derived Mesenchymal Stem } \\
\text { Cells }\end{array}$ & 40 & Not Recruiting & NCT04341610 \\
\hline $\begin{array}{l}\text { Cell Therapy Using Umbilical Cord-derived } \\
\text { Mesenchymal Stromal Cells in SARS-CoV-2- } \\
\text { related ARDS }\end{array}$ & $\begin{array}{l}\text { Umbilical cord Wharton's } \\
\text { jelly-derived human } \\
\text { Mesenchymal Stromal Cells }\end{array}$ & 60 & Not Recruiting & NCT04333368 \\
\hline $\begin{array}{l}\text { Study of Human Umbilical Cord Mesenchymal } \\
\text { Stem Cells in the Treatment of Novel } \\
\text { Coronavirus Severe Pneumonia }\end{array}$ & $\begin{array}{l}\text { Umbilical Cord Mesenchymal } \\
\text { Stem Cells }\end{array}$ & 48 & Not Recruiting & NCT04273646 \\
\hline $\begin{array}{l}\text { Mesenchymal Stem Cell Treatment for } \\
\text { Pneumonia Patients Infected With } 2019 \text { Novel } \\
\text { Coronavirus }\end{array}$ & Mesenchymal Stem Cells & 20 & Recruiting & NCT04252118 \\
\hline $\begin{array}{l}\text { Stem Cell Educator Therapy Treated the Viral } \\
\text { Inflammation Caused by Severe Acute } \\
\text { Respiratory Syndrome Coronavirus } 2\end{array}$ & $\begin{array}{l}\text { Combination Product: Stem } \\
\text { Cell Educator- Treated } \\
\text { Mononuclear Cells Apheresis }\end{array}$ & 20 & Not Recruiting & NCT04299152 \\
\hline $\begin{array}{l}\text { Therapy for Pneumonia Patients Infected by } \\
2019 \text { Novel Coronavirus }\end{array}$ & $\begin{array}{l}\text { Umbilical Cord Mesenchymal } \\
\text { Stem Cells }\end{array}$ & 0 & Withdrawn & NCT04293692 \\
\hline $\begin{array}{l}\text { Umbilical Cord(UC)-Derived Mesenchymal } \\
\text { Stem Cells(MSCs) Treatment for the } \\
\text { 2019-novel Coronavirus(n COV) Pneumonia }\end{array}$ & $\begin{array}{l}\text { Umbilical Cord Mesenchymal } \\
\text { Stem Cells }\end{array}$ & 10 & Recruiting & NCT04269525 \\
\hline $\begin{array}{l}\text { NK Cells Treatment for Novel Coronavirus } \\
\text { Pneumonia }\end{array}$ & NK Cells & 30 & Recruiting & NCT04280224 \\
\hline $\begin{array}{l}\text { A Pilot Clinical Study on Inhalation of } \\
\text { Mesenchymal Stem Cells Exosomes Treating } \\
\text { Severe Novel Coronavirus Pneumonia }\end{array}$ & $\begin{array}{l}\text { Mesenchymal Stem Cells- } \\
\text { derived Exosomes }\end{array}$ & 30 & Not Recruiting & NCT04276987 \\
\hline
\end{tabular}


different animal models and strains to examine the inter-individual genetic diversity and to different species in response to MSCs-based treatments. Additionally, the role of culture conditions in MSC growth is an important issue which needs to be further studied. For instance, the role of the MSCs in controlling the immune microenvironment can be influenced by the development of tissue engineering (TE) technology (Frank and Sayegh 2004). On the other hand, some genetic engineering strategies are investigating to enhance the remedial efficacy of MSCs via rising cell delivery or the impressive dose of trophic agents to the damaged tissue (Saeedi et al. 2019). Furthermore, the development of new diagnostic techniques based on molecular science and OMICS technology can assist better treatment of COVID-19 by increasing information about the novel coronavirus.

Funding We did not receive any funding from any institution.

\section{Compliance with ethical standards}

Conflict of interest There is no conflict of interest.

Ethical approval This article does not contain any studies with animals and human participants performed by any of the authors.

\section{References}

Aghayan HR, Goodarzi P, Arjmand B (2014) GMP-compliant human adipose tissue-derived mesenchymal stem cells for cellular therapy. In: Stem cells and good manufacturing practices, Springer, New York, pp 93-107

Angeletti S, Benvenuto D, Bianchi M, Giovanetti M, Pascarella S, Ciccozzi M (2020) COVID-2019: the role of the nsp2 and nsp3 in its pathogenesis. J Med Virol 92(6):584-588

Applegate WB, Ouslander JG (2020) COVID-19 presents high risk to older persons. J Am Geriatr Soc 68(4):681

Arjmand B, Larijani B, Heshmat R, Norouzi-Javidan A, Soleimani M, Aghayan HR (2014) The current state of clinical cell transplantation trials in Iran: a survey in 2011. Arch NeuroSci 1:7-14

Aslam S, Mehra MR (2020) COVID-19: yet another coronavirus challenge in transplantation. J Heart Lung Transp 39(5):408-409

Baradaran-Rafii A, Sarvari M, Alavi-Moghadam S, Payab M, Goodarzi P, Aghayan HR, Larijani B, Rezaei-Tavirani M, Biglar M, Arjmand B (2020) Cell-based approaches towards treating age-related macular degeneration. In: Cell and tissue banking, pp 1-9

Benítez-Guerra D, Piña-Flores C, Zamora-López M, EscalantePadrón F, Lima-Rogel V, González-Ortiz AM, Guevara-
Tovar M, Bernal-Silva S, Benito-Cruz B, Castillo-Martínez F (2020) Respiratory syncytial virus acute respiratory infection-associated hospitalizations in preterm Mexican infants: a cohort study. Influenza Other Respir Viruses 14:182-188

Bernheim A, Mei X, Huang M, Yang Y, Fayad ZA, Zhang N, Diao K, Lin B, Zhu X, Li K (2020) Chest ct findings in coronavirus disease-19 (covid-19): relationship to duration of infection. Radiology 200463.

Bhuyan GS, Hossain MA, Sarker SK, Rahat A, Islam MT, Haque TN, Begum N, Qadri SK, Muraduzzaman A, Islam NN (2017) Bacterial and viral pathogen spectra of acute respiratory infections in under-5 children in hospital settings in Dhaka city. PloS One 12(3):e0174488

Botti C, Micillo A, Ricci G, Russo A, Denisco A, Cantile M, Scognamiglio G, De Rosa A, Botti G (2018) Characterization of respiratory infection viruses in hospitalized children from Naples province in Southern Italy. Exp Ther Med 15(6):4805-4809

Broekman W, Khedoe PP, Schepers K, Roelofs H, Stolk J, Hiemstra PS (2018) Mesenchymal stromal cells: a novel therapy for the treatment of chronic obstructive pulmonary disease? Thorax 73(6):565-574

Bulla A, Hitze K (1978) Acute respiratory infections: a review. Bull World Health Organ 56(3):481

Caballero MT, Bianchi AM, Nuño A, Ferretti AJP, Polack LM, Remondino I, Rodriguez MG, Orizzonte L, Vallone F, Bergel E, Polack FP (2018) Mortality associated with acute respiratory infections among children at home. J Infect Dis 219(3):358-364

Caretti A, Peli V, Colombo M, Zulueta A (2020) Lights and shadows in the use of mesenchymal stem cells in lung inflammation, a poorly investigated topic in cystic fibrosis. Cells 9(1):20

Cascella M, Rajnik M, Cuomo A, Dulebohn SC, Di Napoli R (2020) Features, evaluation and treatment coronavirus (COVID-19). StatPearls [Internet], StatPearls Publishing

Chen J, Hu C, Chen L, Tang L, Zhu Y, Xu X, Chen L, Gao H, Lu X, Yu L, Dai X, Xiang C, Li L (2020a) Clinical study of mesenchymal stem cell treatment for acute respiratory distress syndrome induced by epidemic influenza a (H7N9) infection: a hint for COVID-19 treatment. Engineering

Chen N, Zhou M, Dong X, Qu J, Gong F, Han Y, Qiu Y, Wang J, Liu Y, Wei Y (2020b) Epidemiological and clinical characteristics of 99 cases of 2019 novel coronavirus pneumonia in Wuhan, China: a descriptive study. The Lancet 395(10223):507-513

Chen Y, Liu Q, Guo D (2020c) Emerging coronaviruses: genome structure, replication, and pathogenesis. J Med Virol 92:418-423

Cheng Y, Luo R, Wang K, Zhang M, Wang Z, Dong L, Li J, Yao $\mathrm{Y}, \mathrm{Ge} \mathrm{S}, \mathrm{Xu} \mathrm{G}$ (2020) Kidney impairment is associated with in-hospital death of COVID-19 patients. MedRxiv

Cong Y-Y (2019) Molecular insights into viral respiratory infections. University of Groningen, Groningen

Control CD (2020) Interim clinical guidance for management of patients with confirmed coronavirus disease (COVID-19).

Coverstone AM, Wang L, Sumino K (2019) Beyond respiratory syncytial virus and rhinovirus in the pathogenesis and exacerbation of asthma: the role of metapneumovirus, 
bocavirus and influenza virus. Immunol Allergy Clin 39(3):391-401

Crane MJ, Lee KM, FitzGerald ES, Jamieson AM (2018) Surviving deadly lung infections: innate host tolerance mechanisms in the pulmonary system. Front Immunol 9:1421-1421

Dagne H, Andualem Z, Dagnew B, Taddese AA (2020) Acute respiratory infection and its associated factors among children under-five years attending pediatrics ward at University of Gondar Comprehensive Specialized Hospital, Northwest Ethiopia: institution-based cross-sectional study. BMC Pediatrics 20(1):93

Dandachi D, Rodriguez-Barradas MC (2018) Viral pneumonia: etiologies and treatment. J Investig Med 66(6):957-965

Diao B, Wang C, Tan Y, Chen X, Liu Y, Ning L, Chen L, Li M, Liu Y, Wang G (2020) Reduction and functional exhaustion of T cells in patients with Coronavirus Disease 2019 (COVID-19). Medrxiv

Dioverti MV, Cawcutt KA, Schears GJ, Baddour LM (2016) Use of extracorporeal membrane oxygenation for the treatment of influenza-induced acute respiratory distress syndrome in immunocompromised adults. Am J Med Sci 352(1):81-85

Ditt V, Lüsebrink J, Tillmann RL, Schildgen V, Schildgen O (2011) Respiratory infections by HMPV and RSV are clinically indistinguishable but induce different host response in aged individuals. PloS One 6(1):e16314

English K, Ryan J, Tobin L, Murphy M, Barry F, Mahon B (2008) Cell contact, prostaglandin E2 and transforming growth factor beta 1 play non redundant roles in Human Mesenchymal Stem Cell Induction of CD4 + CD25 High Foxp3 + Regulatory $\mathrm{T}$ cells. Clin Exp Immunol 156:149-160

Esther CR Jr, Lin FC, Kerr A, Miller MB, Gilligan PH (2014) Respiratory viruses are associated with common respiratory pathogens in cystic fibrosis. Pediatr Pulmonol 49(9):926-931

Fan E, Brodie D, Slutsky AS (2018) Acute respiratory distress syndrome: advances in diagnosis and treatment. JAMA 319(7):698-710

Fan Z, Chen L, Li J, Tian C, Zhang Y, Huang S, Liu Z, Cheng J (2020) Clinical features of COVID-19-related liver damage. Available at SSRN 3546077

Fang L, Karakiulakis G, Roth M (2020) Are patients with hypertension and diabetes mellitus at increased risk for COVID-19 infection? The Lancet Respir Med 8(4):e21

Fehr AR, Perlman S (2015) Coronaviruses: an overview of their replication and pathogenesis. Coronaviruses. Springer, New York, pp 1-23

Ferrarini A, Righetti L, Martínez MP, Fernández-López M, Mastrangelo A, Horcajada JP, Betbesé A, Esteban A, Ordóñez J, Gea J (2017) Discriminant biomarkers of acute respiratory distress syndrome associated to $\mathrm{H} 1 \mathrm{~N} 1$ influenza identified by metabolomics HPLC-QTOF-MS/MS platform. Electrophoresis 38(18):2341-2348

Fisher D, Heymann D (2020) Q\&A: The novel coronavirus outbreak causing COVID-19. BMC Med 18(1):57

Fitzsimmons RE, Mazurek MS, Soos A, Simmons CA (2018) Mesenchymal stromal/stem cells in regenerative medicine and tissue engineering. Stem Cells Int 2018
Frank MH, Sayegh MH (2004) Immunomodulatory functions of mesenchymal stem cells. The Lancet 9419(363):1411-1412

Freeman AM, Soman-Faulkner K, Leigh Jr TR (2019) Viral pneumonia. StatPearls [Internet], StatPearls Publishing

Gattinoni L, Caironi P, Cressoni M, Chiumello D, Ranieri VM, Quintel M, Russo S, Patroniti N, Cornejo R, Bugedo G (2006) Lung recruitment in patients with the acute respiratory distress syndrome. $\mathrm{N}$ Engl $\mathrm{J}$ Med 354(17):1775-1786

Gong J, Dong H, Xia SQ, Huang YZ, Wang D, Zhao Y, Liu W, Tu S, Zhang M, Wang Q, Lu F (2020) Correlation analysis between disease severity and inflammation-related parameters in patients with COVID-19 pneumonia. MedRxiv: 2020.2002.2025.20025643.

Goodarzi P, Aghayan HR, Larijani B, Soleimani M, Dehpour A-R, Sahebjam M, Ghaderi F, Arjmand B (2015) Stem cell-based approach for the treatment of Parkinson's disease. Med J Islamic Republ Iran 29:168

Goodarzi P, Aghayan HR, Soleimani M, Norouzi-Javidan A, Mohamadi-Jahani F, Jahangiri S, Emami-Razavi SH, Larijani B, Arjmand B (2014) Stem cell therapy for treatment of epilepsy. Acta Med Iran 651-655

Goodarzi P, Alavi-Moghadam S, Sarvari M, Beik AT, Falahzadeh K, Aghayan H, Payab M, Larijani B, Gilany K, Rahim F (2018a) Adipose tissue-derived stromal cells for wound healing. Cell Biol Transl Med 4:133-149

Goodarzi P, Larijani B, Alavi-Moghadam S, Tayanloo-Beik A, Mohamadi-Jahani F, Ranjbaran N, Payab M, Falahzadeh K, Mousavi M, Arjmand B (2018b) Mesenchymal stem cells-derived exosomes for wound regeneration. Cell Biol Transl Med 4:119-131

Goodarzi P, Falahzadeh K, Aghayan H, Payab M, Larijani B, Alavi-Moghadam S, Tayanloo-Beik A, Adibi H, Gilany K, Arjmand B (2019a) Therapeutic abortion and ectopic pregnancy: alternative sources for fetal stem cell research and therapy in Iran as an Islamic country. Cell Tissue Banking 20(1):11-24

Goodarzi P, Payab M, Alavi-Moghadam S, Larijani B, Rahim F, Bana N, Sarvari M, Adibi H, Heravani NF, Hadavandkhani M (2019b) Development and validation of Alzheimer's Disease Animal Model for the purpose of regenerative medicine. Cell Tissue Banking 20(2):141-151

Gotts JE, Matthay MA (2011) Mesenchymal stem cells and acute lung injury. Crit Care Clin 27(3):719-733

Graham NM (1990) The epidemiology of acute respiratory infections in children and adults: a global perspective. Epidemiol Rev 12:149-178

Gu H, Chu DK, Peiris JSM, Poon LL (2020) Multivariate analyses of codon usage in 2019 novel coronavirus on the genomic landscape of betacoronavirus. BioRxiv

Guan Y, Zheng B, He Y, Liu X, Zhuang Z, Cheung C, Luo S, Li P, Zhang L, Guan Y (2003) Isolation and characterization of viruses related to the SARS coronavirus from animals in southern China. Science 302(5643):276-278

Guo Y-R, Cao Q-D, Hong Z-S, Tan Y-Y, Chen S-D, Jin H-J, Tan K-S, Wang D-Y, Yan Y (2020) The origin, transmission and clinical therapies on coronavirus disease 2019 (COVID-19) outbreak: an update on the status. Military Med Res 7(1):11 
Hall CB (2001) Respiratory syncytial virus and parainfluenza virus. N Engl J Med 344(25):1917-1928

Harrell CR, Jovicic N, Djonov V, Arsenijevic N, Volarevic V (2019a) Mesenchymal stem cell-derived exosomes and other extracellular vesicles as new remedies in the therapy of inflammatory diseases. Cells 8(12):1605

Harrell CR, Sadikot R, Pascual J, Fellabaum C, Jankovic MG, Jovicic N, Djonov V, Arsenijevic N, Volarevic V (2019b) Mesenchymal stem cell-based therapy of inflammatory lung diseases: current understanding and future perspectives. Stem Cells Int 2019:4236973-4236973

Harrell CR, Sadikot R, Pascual J, Fellabaum C, Jankovic MG, Jovicic N, Djonov V, Arsenijevic N, Volarevic V (2019c) Mesenchymal stem cell-based therapy of inflammatory lung diseases: current understanding and future perspectives. Stem Cells Int

Hassan S, Sheikh FN, Jamal S, Ezeh JK, Akhtar A (2020) Coronavirus (COVID-19): a review of clinical features, diagnosis, and treatment. Cureus 12(3)

Heo JS, Choi Y, Kim HS, Kim HO (2016) Comparison of molecular profiles of human mesenchymal stem cells derived from bone marrow, umbilical cord blood, placenta and adipose tissue. Int $\mathrm{J}$ Mol Med 37(1):115-125

Herridge MS, Tansey CM, Matté A, Tomlinson G, DiazGranados N, Cooper A, Guest CB, Mazer CD, Mehta S, Stewart TE (2011) Functional disability 5 years after acute respiratory distress syndrome. $N$ Engl $J$ Med 364(14):1293-1304

Heymann DL, Shindo N (2020) COVID-19: what is next for public health? The Lancet 395(10224):542-545

Hilgenfeld R, Peiris M (2013) From SARS to MERS: 10 years of research on highly pathogenic human coronaviruses. Antiviral Res 100(1):286-295

Hu W, Su L, Qiao J, Zhu J, Zhou Y (2020) COVID-19 outbreak increased risk of schizophrenia in aged adults

Huh JW, Kim WY, Park YY, Lim C-M, Koh Y, Kim M-J, Hong S-B (2018) Anti-inflammatory role of mesenchymal stem cells in an acute lung injury mouse model. Acute Crit Care 33(3):154-161

Islam MN, Das SR, Emin MT, Wei M, Sun L, Westphalen K, Rowlands DJ, Quadri SK, Bhattacharya S, Bhattacharya J (2012) Mitochondrial transfer from bone-marrow-derived stromal cells to pulmonary alveoli protects against acute lung injury. Nat Med 18(5):759-765

Javanian M, Masrour-Roudsari J, Bayani M, Ebrahimpour S (2020) Coronavirus disease 2019 (COVID-19): What we need to know. Caspian J Intern Med 11(2) Mostafa Javanian (MD) 1

Jiang L, Lee VJM, Cui L, Lin R, Tan CL, Tan LWL, Lim W-Y, Leo Y-S, Low L, Hibberd M (2017) Detection of viral respiratory pathogens in mild and severe acute respiratory infections in Singapore. Sci Rep 7:42963

Jiang W, Xu J (2020) Immune modulation by mesenchymal stem cells. Cell Prolif 53(1):e12712

Jiang F, Deng L, Zhang L, Cai Y, Cheung CW, Xia Z (2020) Review of the clinical characteristics of coronavirus disease 2019 (COVID-19). J General Int Med 1-5

Kim Y-J, Lee ES, Lee Y-S (2019) High mortality from viral pneumonia in patients with cancer. Infect Dis 51(7):502-509
Koo HJ, Lim S, Choe J, Choi S-H, Sung H, Do K-H (2018) Radiographic and CT features of viral pneumonia. Radiographics 38(3):719-739

Kusel MM, de Klerk NH, Holt PG, Kebadze T, Johnston SL, Sly PD (2006) Role of respiratory viruses in acute upper and lower respiratory tract illness in the first year of life: a birth cohort study. Pediatr Infect Dis J 25(8):680-686

Larijani B, Heravani NF, Alavi-Moghadam S, Goodarzi P, Rezaei-Tavirani M, Payab M, Gholami M, Razi F, Arjmand B (2020) Cell therapy targets for autism spectrum disorders: hopes, challenges and future directions

Lee JW, Gupta N, Serikov V, Matthay MA (2009) Potential application of mesenchymal stem cells in acute lung injury. Exp Opin Biol Ther 9(10):1259-1270

Lehtomäki K, Julkunen I, Sandelin K, Salonen J, Virtanen M, Ranki M, Hovi T (1986) Rapid diagnosis of respiratory adenovirus infections in young adult men. J Clin Microbiol 24(1):108-111

Leng Z, Zhu R, Hou W, Feng Y, Yang Y, Han Q, Shan G, Meng F, Du D, Wang S (2020) Transplantation of ACE2-mesenchymal stem cells improves the outcome of patients with COVID-19 pneumonia. Aging Disease 11(2):216-228

Leung NH, Chu DK, Shiu EY, Chan K-H, McDevitt JJ, Hau BJ, Yen H-L, Li Y (2020) Respiratory virus shedding in exhaled breath and efficacy of face masks. Nat Med 26:676-680

Lin L, Yan H, Chen J, Xie H, Peng L, Xie T, Zhao X, Wang S, Shan J (2019) Application of metabolomics in viral pneumonia treatment with traditional Chinese medicine. Chin Med 14(1):8

Lu Q-B, Wo Y, Wang H-Y, Wei M-T, Zhang L, Yang H, Liu E-M, Li T-Y, Zhao Z-T, Liu W (2014) Detection of enterovirus 68 as one of the commonest types of enterovirus found in patients with acute respiratory tract infection in China. J Med Microbiol 63(3):408-414

Luchsinger V, Ampuero S, Palomino MA, Chnaiderman J, Levican J, Gaggero A, Larrañaga CE (2014) Comparison of virological profiles of respiratory syncytial virus and rhinovirus in acute lower tract respiratory infections in very young Chilean infants, according to their clinical outcome. J Clin Virol 61(1):138-144

Ma OK-F, Chan KH (2016) Immunomodulation by mesenchymal stem cells: Interplay between mesenchymal stem cells and regulatory lymphocytes. World J Stem Cells 8(9):268-278

Mackenzie JS, Smith DW (2020) COVID-19: a novel zoonotic disease caused by a coronavirus from China: what we know and what we don't. Microbiol Aust 41(1):45-50

Martin-Rufino JD, Espinosa-Lara N, Osugui L, Sanchez-Guijo F (2019) Targeting the immune system with mesenchymal stromal cell-derived extracellular vesicles: What is the Cargo's mechanism of action? Front Bioeng Biotechnol 7:308-308

Matthay MA, Zemans RL (2011) The acute respiratory distress syndrome: pathogenesis and treatment. Annu Rev Pathol 6(1):147-163

Matthay MA, Zemans RL, Zimmerman GA, Arabi YM, Beitler JR, Mercat A, Herridge M, Randolph AG, Calfee CS (2019) Acute respiratory distress syndrome. Nat Rev Dis Primers 5(1):1-22 
Matthay MA, Aldrich JM, Gotts JE (2020) Treatment for severe acute respiratory distress syndrome from COVID-19. Lancet Respir Med 8(5):433-434

Matuschak GM, Lechner AJ (2010) Acute lung injury and the acute respiratory distress syndrome: pathophysiology and treatment. Mo Med 107(4):252

McGonagle D, Sharif K, O'Regan A, Bridgewood C (2020) Interleukin-6 use in COVID-19 pneumonia related macrophage activation syndrome. Autoimmun Rev 102537

Mehta P, McAuley DF, Brown M, Sanchez E, Tattersall RS, Manson JJ (2020) COVID-19: consider cytokine storm syndromes and immunosuppression. The Lancet 395(10229): 1033

Modena JL, Acrani G, Snider C, Arruda E (2011) Respiratory viruses: influenza virus, respiratory syncytial virus, human metapneumovirus, parainfluenza viruses, rhinovirus, respiratory adenoviruses, coronaviruses (unrelated to SARS), and human bocavirus

Monsel A, Zhu Y, Gennai S, Hao Q, Liu J, Lee JW (2014) Cellbased therapy for acute organ injurypreclinical evidence and ongoing clinical trials using mesenchymal stem cells. Anesthesiol J Am Soc Anesthesiol 121(5):1099-1121

Murthy S, Gomersall CD, Fowler RA (2020) Care for critically ill patients with COVID-19. Jama 323(15):1499-1500

Nichols WG, Campbell AJP, Boeckh M (2008) Respiratory viruses other than influenza virus: impact and therapeutic advances. Clin Microbiol Rev 21(2):274-290

Nye S, Whitley RJ, Kong M (2016) Viral infection in the development and progression of pediatric acute respiratory distress syndrome. Front Pediatr 4(128)

Organization WH (2020) Clinical management of severe acute respiratory infection (SARI) when COVID-19 disease is suspected: interim guidance, 13 March 2020, World Health Organization

Organization WH, WH Organization (2020) Report of the whochina joint mission on coronavirus disease 2019 (covid19). Available on-line: https://www.who.int/docs/defaultsource/coronavirus/who-china-joint-mission-on-covid-19final-report.pdf

Pan F, Ye T, Sun P, Gui S, Liang B, Li L, Zheng D, Wang J, Hesketh RL, Yang L (2020) Time course of lung changes on chest CT during recovery from 2019 novel coronavirus (COVID-19) pneumonia. Radiology 200370

Paules CI, Marston HD, Fauci AS (2020) Coronavirus infections-more than just the common cold. JAMA 323(8):707-708

Payab M, Goodarzi P, Heravani NF, Hadavandkhani M, Zarei Z, Falahzadeh K, Larijani B, Rahim F, Arjmand B (2018) Stem cell and obesity: current state and future perspective. Cell Biol Transl Med 2:1-22

Pham HT, Nguyen PT, Tran ST, Phung TT (2020) Clinical and pathogenic characteristics of lower respiratory tract infection treated at the vietnam national children's hospital. Can J Infect Dis Med Microbiol

Pore PD, Ghattargi CH, Rayate MV (2010) Study of risk factors of Acute Respiratory Infection (ARI) in underfives in Solapur. Nat J Com Med 1(2):64-67

Prompetchara E, Ketloy C, Palaga T (2020) Immune responses in COVID-19 and potential vaccines: Lessons learned from SARS and MERS epidemic. Asian Pac J Allergy Immunol
Quinton LJ, Walkey AJ, Mizgerd JP (2018) Integrative physiology of pneumonia. Physiol Rev 98(3):1417-1464

Rismanbaf A, Zarei S (2020) Liver and kidney injuries in COVID-19 and their effects on drug therapy; a letter to editor. Arch Acad Emerg Med 8(1):17

Ritchie AI, Mallia P, Johnston SL (2017) Viral syndrome infections in humans. Acute Exacerb Pulmonary Dis 77:76

Robb C, Regan K, Dorward D, Rossi A (2016) Key mechanisms governing resolution of lung inflammation. Seminars in immunopathology. New York, Springer

Rothan HA, Byrareddy SN (2020) The epidemiology and pathogenesis of coronavirus disease (COVID-19) outbreak. J Autoimmun 102433

Ruuskanen O, Lahti E, Jennings LC, Murdoch DR (2011) Viral pneumonia. The Lancet 377(9773):1264-1275

Saeedi P, Halabian R, Fooladi AAI (2019) A revealing review of mesenchymal stem cells therapy, clinical perspectives and Modification strategies. Stem Cell Invest 6

Sahin AR, Erdogan A, Agaoglu PM, Dineri Y, Cakirci AY, Senel ME, Okyay RA, Tasdogan AM (2020) 2019 Novel Coronavirus (COVID-19) outbreak: a review of the current literature. EJMO 4(1):1-7

Sama IE, Ravera A, Santema BT, van Goor H, ter Maaten JM, Cleland JGF, Rienstra M, Friedrich AW, Samani NJ, Ng LL, Dickstein K, Lang CC, Filippatos G, Anker SD, Ponikowski P, Metra M, van Veldhuisen DJ, Voors AA (2020) Circulating plasma concentrations of angiotensinconverting enzyme 2 in men and women with heart failure and effects of renin-angiotensin-aldosterone inhibitors. Eur Heart J 41(19):1810-1817

Schildgen O, Schildgen V (2018) The role of the human bocavirus $(\mathrm{HBoV})$ in respiratory infections. Adv Tech Diagnostic Microbiol 281-301

Shereen MA, Khan S, Kazmi A, Bashir N, Siddique R (2020) COVID-19 infection: origin, transmission, and characteristics of human coronaviruses. J Adv Res

Shi T, Denouel A, Tietjen AK, Campbell I, Moran E, Li X, Campbell H, Demont C, Nyawanda BO, Chu HY (2019) Global disease burden estimates of respiratory syncytial virus-associated acute respiratory infection in older adults in 2015: a systematic review and meta-analysis. J Infect Dis 352

Shi T, McLean K, Campbell H, Nair H (2015) Aetiological role of common respiratory viruses in acute lower respiratory infections in children under five years: a systematic review and meta-analysis. J Global Health 5(1)

Singh S, Chakravarty T, Chen P, Akhmerov A, Falk J, Friedman O, Zaman T, Ebinger JE, Gheorghiu M, Marbán L (2020) Allogeneic cardiosphere-derived cells (CAP-1002) in critically ill COVID-19 patients: compassionate-use case series. Basic Res Cardiol 115(4)

Smyth RL, Openshaw PJ (2006) Bronchiolitis. The Lancet 368(9532):312-322

Stoecklin SB, Rolland P, Silue Y, Mailles A, Campese C, Simondon A, Mechain M, Meurice L, Nguyen M, Bassi C (2020) First cases of coronavirus disease 2019 (COVID19) in France: surveillance, investigations and control measures, January 2020. Eurosurveillance 25(6)

Syrmis MW, Whiley DM, Thomas M, Mackay IM, Williamson J, Siebert DJ, Nissen MD, Sloots TP (2004) A sensitive, specific, and cost-effective multiplex reverse transcriptase- 
PCR assay for the detection of seven common respiratory viruses in respiratory samples. J Mol Diagn 6(2):125-131

Tamura S-I, Kurata T (2004) Defense mechanisms against influenza virus infection in the respiratory tract mucosa. Jpn J Infect Dis 57(6):236-247

Team EE (2020) Updated rapid risk assessment from ECDC on the novel coronavirus disease 2019 (COVID-19) pandemic: increased transmission in the EU/EEA and the UK. Eurosurveillance 25(10)

Tucci MR, Costa EL, Nakamura MA, Morais CC (2016) Noninvasive ventilation for acute respiratory distress syndrome: the importance of ventilator settings. J Thoracic Dis 8(9):E982

Turkington C, Ashby B (2007) The encyclopedia of infectious diseases. Infobase Publishing, New York

Turner RB (2007) Rhinovirus: more than just a common cold virus. J Infect Dis 195(6):765-766

van Doorn HR, Yu H (2020) Viral respiratory infections. Hunter's tropical medicine and emerging infectious diseases, Elsevier: New York, pp 284-288

Virani A, Ma K, Leap J, Dumont T, Hertel J, Singh A, Cheema T (2019) Acute respiratory distress syndrome definition, causes, and pathophysiology. Critical Care Nursing Q 42(4):344-348

Wang Q, Ding G, Xu X (2016) Immunomodulatory functions of mesenchymal stem cells and possible mechanisms. Histol Histopathol 31(9):949-959

Wang M, Yuan Q, Xie L (2018) Mesenchymal Stem Cell-Based Immunomodulation: properties and clinical application. Stem Cells Int 2018:3057624-3057624

Wang H, Luo S, Shen Y, Li M, Zhang Z, Dong Y, Zhou H, Lin L, Guo W, Kang Z (2020a) Multiple enzyme release, inflammation storm and hypercoagulability are prominent indicators for disease progression In COVID-19: a multicentered, correlation study with ct imaging score

Wang J, Luo Q, Chen R, Chen T, Li J (2020b) Susceptibility analysis of COVID-19 in smokers based on ACE2

Ware LB, Matthay MA (2000) The acute respiratory distress syndrome. N Engl J Med 342(18):1334-1349
Weiss ARR, Dahlke MH (2019) Immunomodulation by mesenchymal stem cells (MSCs): mechanisms of action of living, apoptotic, and dead MSCs. Front Immunol 10(1191)

Wu Z, McGoogan JM (2020) Characteristics of and important lessons from the coronavirus disease 2019 (COVID-19) Outbreak in China: Summary of a Report of 72314 Cases From the Chinese Center for Disease Control and Prevention. JAMA

Wu C, Hu X, Song J, Du C, Xu J, Yang D, Chen D, Zhong M, Jiang J, Xiong W (2020) Heart injury signs are associated with higher and earlier mortality in coronavirus disease 2019 (COVID-19). MedRxiv

Xu D, Zhang H, Gong H, Chen J, Ye J, Meng T, Gan S, Qu F, Chu C, Zhou W (2020) Identification of a potential mechanism of acute kidney injury during the covid-19 outbreak: a study based on single-cell transcriptome analysis

Xu Z, Shi L, Wang Y, Zhang J, Huang L, Zhang C, Liu S, Zhao P, Liu H, Zhu L (2020) Pathological findings of COVID-19 associated with acute respiratory distress syndrome. The Lancet Respir Med

Yin Y, Wunderink RG (2018) MERS, SARS and other coronaviruses as causes of pneumonia. Respirology 23(2):130-137

Zhou P, Yang X-L, Wang X-G, Hu B, Zhang L, Zhang W, Si H-R, Zhu Y, Li B, Huang C-L, Chen H-D, Chen J, Luo Y, Guo H, Jiang R-D, Liu M-Q, Chen Y, Shen X-R, Wang X, Zheng X-S, Zhao K, Chen Q-J, Deng F, Liu L-L, Yan B, Zhan F-X, Wang Y-Y, Xiao G-F, Shi Z-L (2020) A pneumonia outbreak associated with a new coronavirus of probable bat origin. Nature 579(7798):270-273

Publisher's Note Springer Nature remains neutral with regard to jurisdictional claims in published maps and institutional affiliations. 